\title{
Synergistic generation of energy and water in remote communities: Economic and environmental assessment of current situation and future scenarios
}

DOI:

10.1016/j.enconman.2020.112543

\section{Document Version \\ Accepted author manuscript}

Link to publication record in Manchester Research Explorer

Citation for published version (APA):

Aberilla, J. M., Gallego Schmid, A., Stamford, L., \& Azapagic, A. (2020). Synergistic generation of energy and water in remote communities: Economic and environmental assessment of current situation and future scenarios. Energy Conversion and Management. https://doi.org/10.1016/j.enconman.2020.112543

\section{Published in:}

Energy Conversion and Management

\section{Citing this paper}

Please note that where the full-text provided on Manchester Research Explorer is the Author Accepted Manuscript or Proof version this may differ from the final Published version. If citing, it is advised that you check and use the publisher's definitive version.

\section{General rights}

Copyright and moral rights for the publications made accessible in the Research Explorer are retained by the authors and/or other copyright owners and it is a condition of accessing publications that users recognise and abide by the legal requirements associated with these rights.

\section{Takedown policy}

If you believe that this document breaches copyright please refer to the University of Manchester's Takedown Procedures [http://man.ac.uk/04Y6Bo] or contact uml.scholarlycommunications@manchester.ac.uk providing relevant details, so we can investigate your claim.

\section{OPEN ACCESS}




\title{
Synergistic generation of energy and water in remote communities: Economic and environmental assessment of current situation and future scenarios
}

\author{
Jhud Mikhail Aberilla $^{\mathrm{a}, \mathrm{b}}$, Alejandro Gallego-Schmid ${ }^{\mathrm{a}, \mathrm{c}}$, Laurence Stamford ${ }^{\mathrm{a}}$ and Adisa Azapagic ${ }^{\mathrm{a},{ }^{*}}$ \\ a Sustainable Industrial Systems, Department of Chemical Engineering and Analytical Science, The University of \\ Manchester, The Mill, Sackville Street, Manchester M13 9PL, UK \\ b Department of Chemical Engineering, University of the Philippines, C.P. Garcia Avenue, Diliman, Quezon City 1101, \\ Philippines \\ c Tyndall Centre for Climate Change Research, Department of Mechanical, Aerospace and Civil Engineering, The \\ University of Manchester, Pariser Building, Sackville Street, Manchester M13 9PL, UK \\ * Corresponding author. E-mail address: adisa.azapagic@manchester.ac.uk (A. Azapagic).
}

\begin{abstract}
Improving access to energy and water in remote communities is an important step towards sustainable development. However, integrated sustainability studies at the community or household scale are rare compared to industrial or national studies. Thus, this paper presents an integrated approach to the development and evaluation of energy and water supply systems in remote communities in developing countries. Termed here "synergistic generation" ("synergen"), the approach considers simultaneously electricity, heat for cooking and water supply to determine their environmental and economic sustainability on a life cycle basis. Life cycle assessment and life cycle costing are used for this purpose. Both the current situation and future scenarios to 2030 are considered for a representative remote community. The life cycle costs of the current energy and water supply are estimated at 2,944 USD/ household per year, most of which $(91 \%)$ is due to bottled water. The latter is also the main cause of current environmental impacts $(62 \%)$, followed by cooking fuels (33\%) and electricity (5\%). If business as usual (BAU) continues to 2030, air pollution and eutrophication could be reduced by $>40 \%$ but other 14 impacts would increase by 2$63 \%$ on the current situation due to higher dependence on diesel for electricity generation and bottled water. For the same reason, BAU also has $82 \%$ higher life cycle costs $(5,364$ USD/household·yr) than at present. Assuming full supply self-sufficiency (Independent scenario) leads to a $>12 \%$ reduction in all impact categories, except terrestrial ecotoxicity, which increases by $5 \%$ - both trends are due to utilisation of waste biomass for cooking. The life cycle costs are reduced by $92 \%$ ( $231 \mathrm{USD} /$ household $\cdot \mathrm{yr}$ ), mainly due to the phasing out of bottled water. However, capital costs are $21 \%$ higher due to the need for multiple renewable energy installations. Pursuing moderate rather than full independence of supply (Transition scenario) would reduce most impacts and costs below those of the current situation. Overall, the Transition and Independent scenarios have lower impacts than at present in almost all environmental categories as well as lower life cycle costs. These findings demonstrate the environmental and economic feasibility of energy and water independence in remote communities as well as highlighting the likely trade-offs that should be considered during the transition.
\end{abstract}

Keywords: Household cooking heat; Life cycle assessment; Life cycle costing; Off-grid electricity; Rural development. 


\section{Nomenclature}

\begin{tabular}{|c|c|c|c|}
\hline$A C C_{j}$ & $\begin{array}{l}\text { Annualised capital costs of technology/option j } \\
\text { (USD/yr) }\end{array}$ & LCC & Total life cycle cost (USD/hh·yr) \\
\hline C & Set of cooking fuels & LCOE & Levelised cost of electricity (USD/hh·yr) \\
\hline $\mathrm{CC}_{\mathrm{j}}$ & Capital costs of technology/option j (USD) & $\mathrm{LCOH}$ & Levelised cost of cooking heat (USD/hh·yr) \\
\hline $\mathrm{CFC}_{\mathrm{hh}}$ & $\begin{array}{l}\text { Annual cooking heat consumption per } \\
\text { household }(\mathrm{MJ} / \mathrm{hh} \cdot \mathrm{yr})\end{array}$ & LCOW & Levelised cost of locally-produced water (USD/hh-yr) \\
\hline CFS & $\begin{array}{l}\text { Total cooking heat consumption of by the } \\
\text { community (MJ/yr) }\end{array}$ & $\mathrm{n}$ & Lifetime of technology/option j (yr) \\
\hline$E$ & Set of electricity generation components & $\mathrm{OMC}_{\mathrm{j}}$ & $\begin{array}{l}\text { Operating and maintenance costs of technology/option } \\
\text { j (USD/yr) }\end{array}$ \\
\hline $\mathrm{EC}_{\mathrm{hh}}$ & $\begin{array}{l}\text { Annual electricity consumption per household } \\
(\mathrm{kWh} / \mathrm{hh} \cdot \mathrm{yr})\end{array}$ & PCBW & $\begin{array}{l}\text { Annual purchase costs of imported bottled water } \\
\text { (USD/hh·yr) }\end{array}$ \\
\hline$E l_{j, k}$ & $\begin{array}{l}\text { Unit environmental impact } \mathrm{k} \text { from } \\
\text { technology/option j for each utility (per kWh, MJ } \\
\text { or } \mathrm{m}^{3} \text { ) }\end{array}$ & $V_{\mathrm{j}}$ & Annual variable costs of technology/option j (USD/yr) \\
\hline$E l_{k, h h}$ & Total annual environmental impact k per & W & Set of water supply options \\
\hline ES & $\begin{array}{l}\text { Total electricity consumption by the community } \\
\text { (kWh/yr) }\end{array}$ & $W_{h h}$ & Annual water consumption per household $\left(\mathrm{m}^{3} / \mathrm{hh} \cdot \mathrm{yr}\right)$ \\
\hline $\mathrm{FC}_{\mathrm{j}}$ & $\begin{array}{l}\text { Annual fixed costs of technology/option j } \\
\text { (USD/yr) }\end{array}$ & WS & Total water consumption by the community $\left(\mathrm{m}^{3} / \mathrm{yr}\right)$ \\
\hline$f C j$ & Fuel costs of technology/option j (USD/yr) & $X_{j}$ & Share of technology/option $\mathrm{j}$ in the supply mix (-) \\
\hline
\end{tabular}

\section{Introduction}

Access to electricity, clean cooking and safe water is identified as key for achieving many of the United Nations' Sustainable Development Goals (SDG) [1]. While progress has been made in recent years, the rate of population growth overtakes the improvement of access in many developing countries for both energy [2] and water [3]. Planning of energy and water services in these regions is further complicated by the complex interactions of these resources within the energy-water nexus [4]. For example, distributed electricity generation, such as production of biogas from manure, can affect quality of water supply due to the leachates from the digestate [5].

Methodologies in systems engineering have been highlighted as effective tools for incorporating the nexus into conventional engineering design and policy formulation [6]. Previous studies have used integrated modelling frameworks including systems dynamics [7], agent-based modelling and network optimisation [4], superstructures [8], process simulation [9] and life cycle assessment (LCA) [10] to address the nexus in energy and water production systems. For example, Leung Pah Hang et al. [8] developed an integrated model for food, energy and water production for a masterplanned greenfield eco-town. The study highlighted that co-designing the sub-systems, compared to designing each supply chain separately, reveals the synergies and new options available to designers. However, the authors noted that their problem formulation is not applicable for preexisting installations. In a similar study, Al-ansari et al. [10] showed how extending the scope of LCA to the energy-water-food nexus can relate consumption and production at a national level to an overall environmental impact. However, compared to the national or regional levels, studies of the nexus at the household and community scales are limited. One such study [7] used a scenario analysis to consider the interactions between water-energy-food parameters and the drivers of household consumption. Furthermore, the previous studies have considered only one dimension of sustainability (e.g. economic or environmental) so that their trade-offs remain unexplored.

A related concept in simultaneous energy and water production is polygeneration, a term used to describe integrated processes which provide multiple products, such as fuels, chemicals [11] and utilities [12]. Although many studies in polygeneration design focus on industrial-scale production, there is a growing interest in smaller scale polygeneration systems [13]. Previous studies on polygeneration for remote communities presented designs sized to meet the demand at a certain location. For example, Khan et al. [14] performed a techno-economic analysis of a biogas system to meet the electricity, cooking and water demands of a 30-household village in Bangladesh. While their design provided acceptable levelised costs of utilities, capital costs and biomass availability were the key barriers for implementation. A poygeneration system proposed by Calise et al. [15] 
consisted of four technologies for supplying electricity, space heating and cooling, as well as water to a sub-urban area of an Italian island. Their work focused on developing the simulation models although they also provided estimates for avoided diesel consumption and its related $\mathrm{CO}_{2}$ emissions. Another study [16] considered a solar-assisted micro-gas turbine system to generate electricity, heat (for domestic hot water) and space cooling for a remote village of 25-50 households in Israel. In comparison to the existing diesel generator, air conditioning units and diesel-fired water heaters, this system had lower costs and $\mathrm{CO}_{2}$ emissions. However, all these analyses suppose that existing utility systems are not present or are completely replaced by the proposed design. Furthermore, dependence on a single polygeneration facility to provide for the utility requirements of a community affects the security of supply, especially in disaster-prone areas. Besides, in some instances, replacing current systems with polygeneration does not lead to environmental benefits. This is the case, for example, when the carbon intensity of the current system is sufficiently low compared to achievable efficiencies of combined systems [17]. Therefore, there is a need for comprehensive life cycle assessments to determine whether integrated energy and water systems are beneficial environmentally.

To address some of the above deficiencies of single-plant polygeneration of off-grid utilities, this paper proposes an alternative approach by considering multiple production systems working in synergy with each other within the energy-water nexus. Rather than constraining the design space to a single installation to provide all of the demands, the proposed approach - termed here "synergen" - investigates and takes advantage of multiple and intersecting supply chains. The study combines scenario analysis, techno-economic simulation and optimisation, life cycle costing (LCC) and LCA to design economically and environmentally sustainable systems for supplying electricity, cooking heat and water in remote communities to benefit from synergies that exist between them. This work contributes to the literature by providing an alternative approach in the planning, design and evaluation off-grid utility systems. Furthermore, it demonstrates the potential of remote communities to have independent utility systems that have improved economic and environmental performance compared to the current situation. As far as the authors are aware, this is the first study of its kind internationally.

\section{Methods}

As outlined in Figure 1, the methodology applied in this study comprises the following steps: i) definition of the goal and scope of the study; ii) definition of the current energy and water supply systems and simulation of the electricity supply; iii) definition of future scenarios and design and optimisation of feasible electricity synergen systems; and iv) evaluation of the economic and environmental sustainability of the current situation and future scenarios to identify the most sustainable option(s).

HOMER Pro [18] has been utilised to simulate the current electricity system as well as to design and optimise future electricity systems according to different scenarios. The economic sustainability has been evaluated via LCC in accordance with the methodology proposed by Swarr et al. [19]. LCA has been used to assess the environmental sustainability, following the guidelines in ISO 14040/14044 [20,21] and taking an attributional approach. The above methodological steps are described in turn in the next sections.

\section{$2.1 \quad$ Goal and scope definition}

As previously mentioned, the goal of the study is to design environmentally and economically sustainable energy and water systems for remote communities, to maximise the benefits of their synergistic interactions. Both the current situation and possible future scenarios are considered. The base year for the current situation is 2015 , based on data availability. For the scenarios, the year 2030 has been selected to correspond to the time horizon of the SDG. 


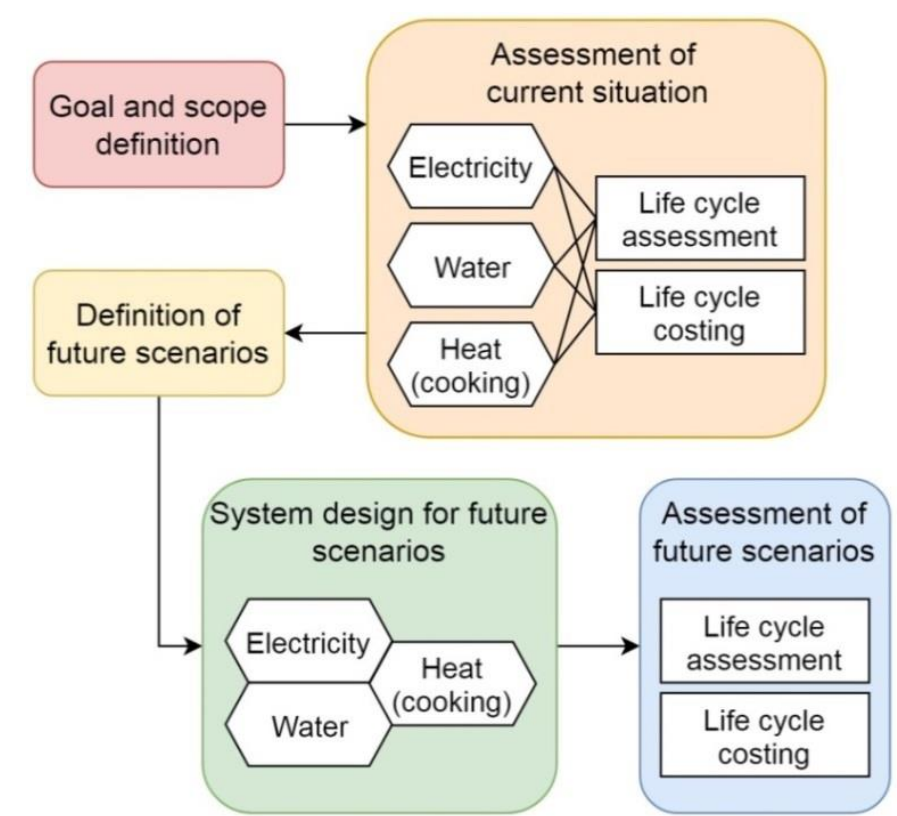

Figure 1. Methodology for designing and evaluating the sustainability of synergen systems

The Philippines has been selected as the geographical context for the study. This is due to its numerous off-grid small-island communities [22] and the country's ambition to transition towards sustainable energy [23]. The average community in off-grid islands has 4,534 households (with on average four persons) [24], forecasted to grow to 5,588 households by 2030 [25]. As an archipelagic nation, the Philippines has a rural electrification rate of $85 \%$, leaving an estimated 11 million people without electricity as of 2016 [26]. Only $45 \%$ of the population has access to clean fuels and technologies, making the Philippines one of the bottom 20 countries in the world [2]. Water access, as measured by having 'basic water service', is at $90.5 \%$ in the country, but a gap of more than 10 points exists between urban (96.4\%) and rural (85.8\%) areas [27]. Similar conditions exist in island and other remote communities in the rest of Southeast Asia as well as in the Caribbean and Oceania [28].

The analysis is based on the functional unit defined as "annual consumption of electricity, cooking fuels and water per household". Assuming basic access to the utilities in the remote communities in the region, this is equivalent to $100 \mathrm{kWh}$ of electricity [29], 4.87 GJ of heat for cooking [30] and $197 \mathrm{~m}^{3}$ of water [31]. Space heating is not considered due to the tropical climate; cooling is excluded at this basic level of energy access.

The scope of the study is from cradle to grave, comprising raw materials extraction, installation, maintenance, use and eventual end of life of facilities. Figure 2 shows the system boundary for the life cycles of electricity, cooking and water supply as well as their synergistic interactions. For example, biomass is used for electricity generation and as a cooking fuel, while electricity is consumed for cooking (electric stoves) and water extraction. The infrastructure and the fuels considered in the study are also given in Figure 2.

\section{$2.2 \quad$ Current situation}

As is the case for most remote communities, off-grid power systems in the Philippines are dominated by diesel generators ( $>96 \%$ of capacity and generation) [22]. The operation of the diesel generator has been simulated in HOMER, considering the residential load profile (Figure 3) and the power required for water production (Table 1). Techno-economic parameters, such as fuel consumption and operating costs, have been obtained through the simulation. For further details, see Aberilla et al. [32]. 


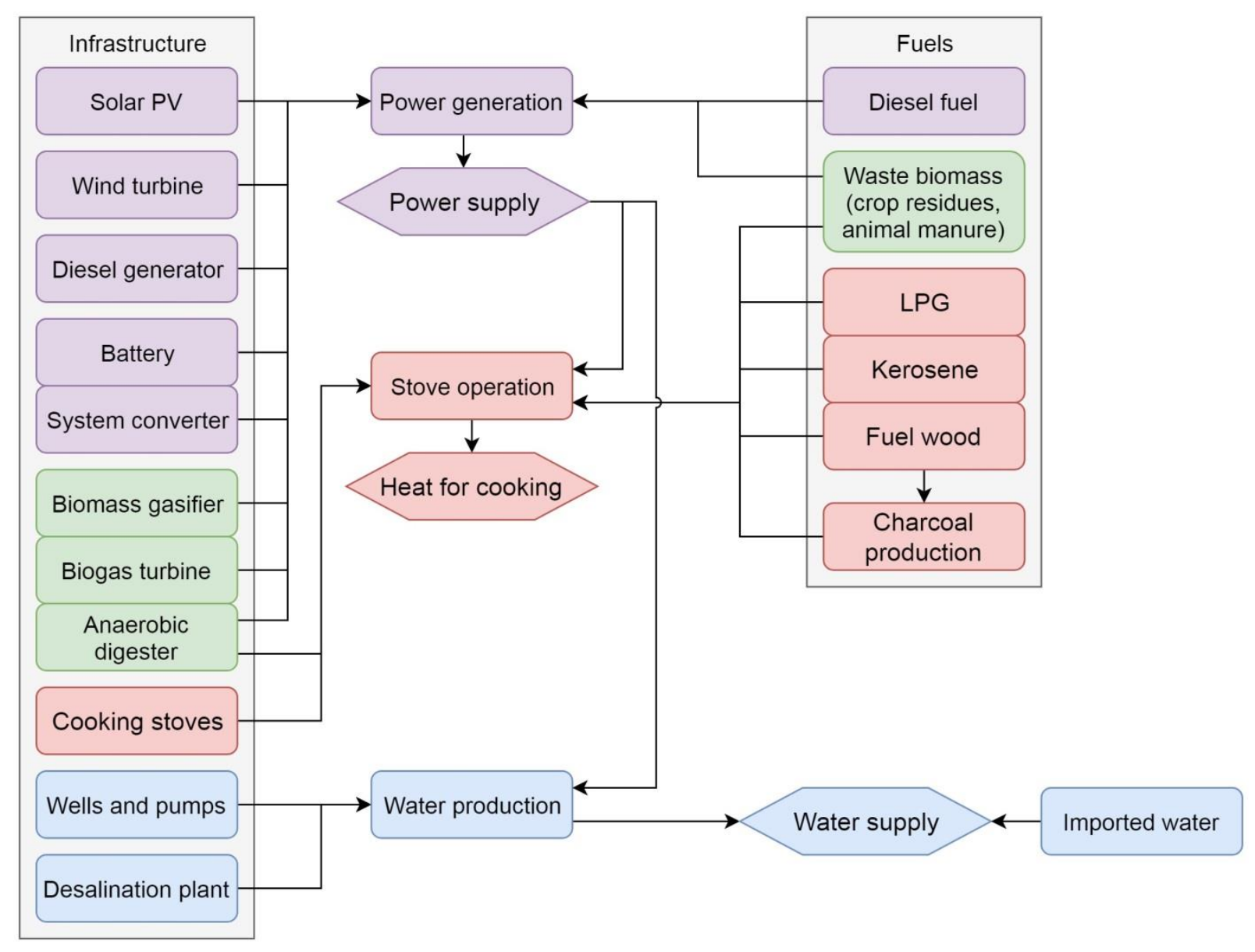

Figure 2. System boundary for the electricity, cooking heat and water synergen system (Upstream processes, transport and end-of-life waste management are not shown but are included in the system. Imported water: bottled water supplied externally.)

The most recent household survey in the Philippines shows that liquefied petroleum gas (LPG) is the preferred heat source for domestic cooking, supplying $39.8 \%$ of the cooking energy demand (Figure 4a) [30]. However, traditional biomass fuels (fuel wood, charcoal and other biomass) are still prevalent in rural areas, with a total share of 55.8\% [33]. For this study, other biomass fuels are taken to be crop residues from rice and coconut farming as these are the most common crops planted in the region [34]. The rest of the cooking fuel demand is met by kerosene (4.4\%).

The water sources used by households in the Philippines [24] are summarised in Figure 4b, excluding those with access to tap water. The fraction of households primarily using water mains corresponds roughly to the fraction of the population residing in urban areas of the country. Hence, it can be inferred that remote communities obtain most of their water from local ground and surface water sources or purchase bottled water. The latter is sourced externally, referred to here as 'imported' water, packaged either in reusable $18.9 \mathrm{~L}$ containers (5 gallon) or single-use $1.5 \mathrm{~L}$ bottles.

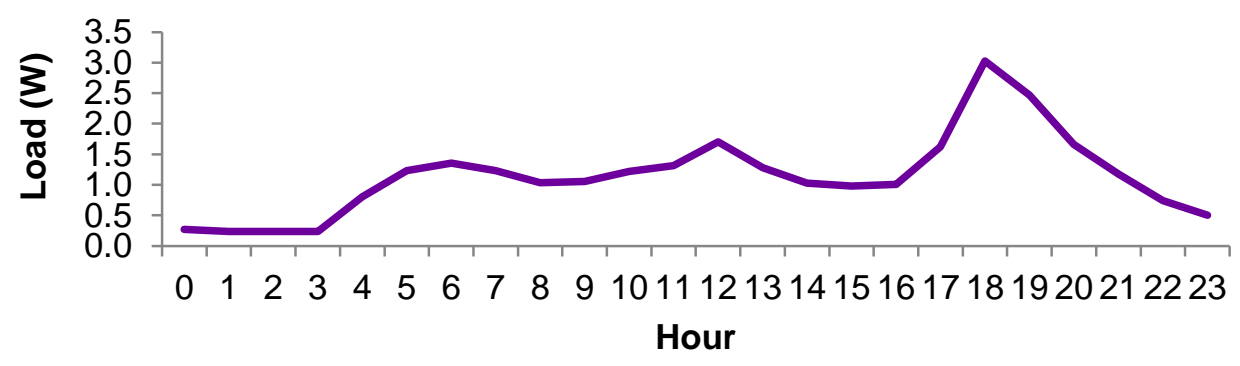

Figure 3. Current hourly residential load profile per household [18] (Total annual electricity consumption: $100 \mathrm{kWh}$ ) 
Table 1. Parameters used in HOMER for simulation of the current electricity supply

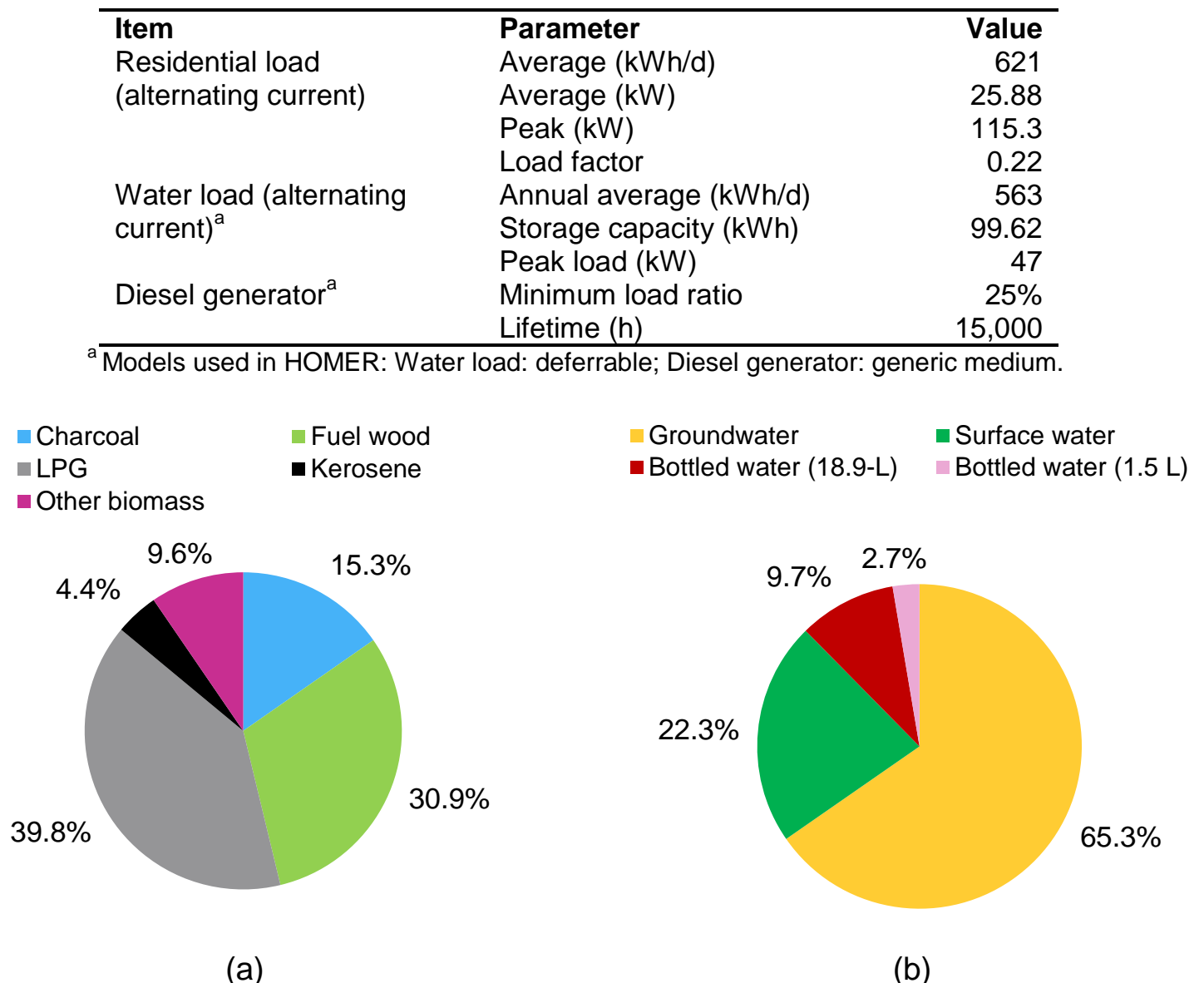

Figure 4. (a) Cooking fuel mix [30] and (b) potable water supply [24] in off-grid Philippine households

[Other biomass fuels are assumed to be crop residues from rice and coconut farming.]

\section{$2.3 \quad$ Future scenarios}

The following three scenarios are considered: Business as usual (BAU), Transition and Independent. They follow different paths in terms of technologies, access and security of supply as described below.

The BAU scenario considers no change in the source of electricity on the current situation. Hence, the off-grid electricity continues to be reliant solely on diesel generators, with capacity expansion expected to meet the demand increase due to the population growth and greater access to energy (Table 2). As indicated in Figure 5, the cooking fuel mix sees an increase in LPG and introduction of biogas to offset the trend of a decreasing use of traditional biomass and kerosene as households move towards cleaner fuel options [35,36]. Only a small fraction of electricity $(<1 \%)$ is used for cooking purposes [29]. Extraction from natural freshwater sources is expected to increase [37], but this will not be enough to match the increase in population; therefore, households are expected to purchase more bottled water as a result (Figure 6).

In the Transition scenario, existing energy and water options are still preferred, but renewable technologies are also introduced in the supply mix. These include solar photovoltaics (PV), wind turbines, bio-syngas from gasification of crop residues and biogas from anaerobic digestion of animal manure. These renewables have been selected as they are recommended for small-scale electrification in developing countries [38]. For the cooking fuel sector, total LPG consumption is kept at current levels, with biogas and traditional biomass filling in the remaining demand in the same proportions as in the BAU scenario (Figure 5). The water supply follows the same trend as in BAU, except that the total imported water is kept constant at current levels and seawater desalination is used to meet the supply gap (Figure 6). The energy-water nexus can be noticed in 
this scenario: animal manure is a common resource for both electricity and cooking fuels, while additional power is required for electric stoves and water desalination.

Table 2. Electricity demand in the current situation and future scenarios

\begin{tabular}{lccrr}
\hline Parameter & $\begin{array}{l}\text { Current } \\
\text { situation }\end{array}$ & Business as usual & Transition & Independent \\
& 4,534 & 5,588 & 5,588 & 5,588 \\
No. of households & 50 & 100 & 100 & 100 \\
Households with electricity (\%) & 100 & $112^{\mathrm{a}}$ & $112^{\mathrm{a}}$ & $112^{\mathrm{a}}$ \\
Residential demand (kWh/hh'yr) & 45 & 40 & 148 & 231 \\
Electricity for water production & & & & \\
(kWh/hh'yr) $_{\text {Total demand (kWh/hhyr) }}^{\mathrm{b}}$ & 95 & 152 & 260 & 343 \\
\hline
\end{tabular}

${ }^{a}$ Including $12 \mathrm{kWh} / \mathrm{hh} \cdot \mathrm{yr}$ of electricity for cooking.

${ }^{\mathrm{b}}$ Total demand $=$ (Number of households $\mathrm{x}$ Percentage of households with access $\times$ Residential demand $)+$ Electricity for water production.

Table 3. Parameters used in HOMER for simulation and optimisation of electricity supply in the future scenarios

\begin{tabular}{|c|c|c|}
\hline Item & Parameter & Value \\
\hline \multirow[t]{3}{*}{ Resources } & Location & $10^{\circ} 16^{\prime} \mathrm{N}, 119^{\circ} 30^{\prime} \mathrm{E}$ \\
\hline & $\begin{array}{l}\text { Average solar resource } \\
\left(\mathrm{kWh} / \mathrm{m}^{2} / \mathrm{d}\right)\end{array}$ & 5.27 \\
\hline & Average wind resource $(\mathrm{m} / \mathrm{s})$ & 5.66 \\
\hline \multirow{4}{*}{$\begin{array}{l}\text { Residential load } \\
\text { (alternating current) }\end{array}$} & Average $(\mathrm{kWh} / \mathrm{d})$ & Varies with scenario (Table 2 ) \\
\hline & Average $(\mathrm{kW})$ & $4 \%$ of daily load \\
\hline & Peak (kW) & $11 \%$ of daily load \\
\hline & Load factor & 0.22 \\
\hline \multirow{4}{*}{$\begin{array}{l}\text { Water load, current } \\
\text { (alternating current, deferrable) } \\
\text { Diesel generator }^{\mathrm{a}}\end{array}$} & Annual average $(\mathrm{kWh} / \mathrm{d})$ & Varies with scenario (Table 2 ) \\
\hline & Storage capacity $(\mathrm{h} / \mathrm{d})$ & 4 \\
\hline & Minimum load ratio & $25 \%$ \\
\hline & Lifetime (h) & 15,000 \\
\hline \multirow[t]{2}{*}{ Solar $\mathrm{PV}^{\mathrm{a}}$} & Derating factor & $80 \%$ \\
\hline & Lifetime $(\mathrm{yr})$ & 30 \\
\hline \multirow[t]{2}{*}{ Wind turbine ${ }^{a}$} & Hub height (m) & 29 \\
\hline & Lifetime (yr) & 20 \\
\hline \multirow{3}{*}{ Li-ion battery ${ }^{a}$} & Initial state of charge & $100 \%$ \\
\hline & Minimum state of charge & $20 \%$ \\
\hline & Degradation limit & $30 \%$ \\
\hline \multirow[t]{3}{*}{ System converter ${ }^{a}$} & Inverter efficiency & $95 \%$ \\
\hline & Rectifier efficiency & $90 \%$ \\
\hline & Lifetime (yr) & 15 \\
\hline \multirow[t]{3}{*}{ Biogas $^{a}$} & Minimum load ratio & $20 \%$ \\
\hline & Reference capacity (kW) & 300 \\
\hline & Lifetime $(\mathrm{h})$ & 50,000 \\
\hline
\end{tabular}

plate; Battery: generic advanced storage module; Converter: generic; Biogas: generic size-your-own. 
$\square$ LPG $\square$ Kerosene $\square$ Charcoal $\square$ Fuel wood $\square$ Crop residues $\square$ Biogas $\square$ Electricity

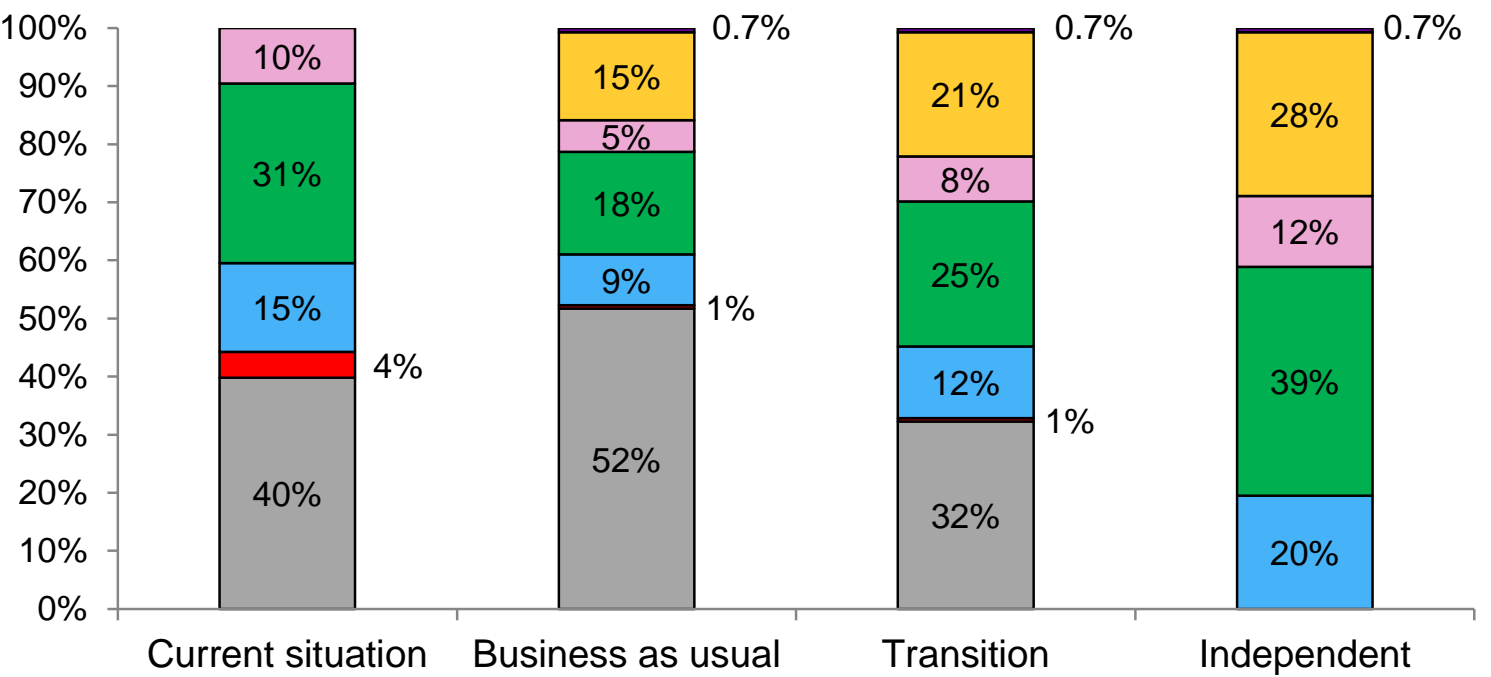

Figure 5. Cooking fuel mix for the current situation and future scenarios

$\square$ Groundwater $\square$ Surface water $\square$ Bottled water $(18.9 \mathrm{~L})$ (Bottled water $(1.5 \mathrm{~L})$ 口Desalination

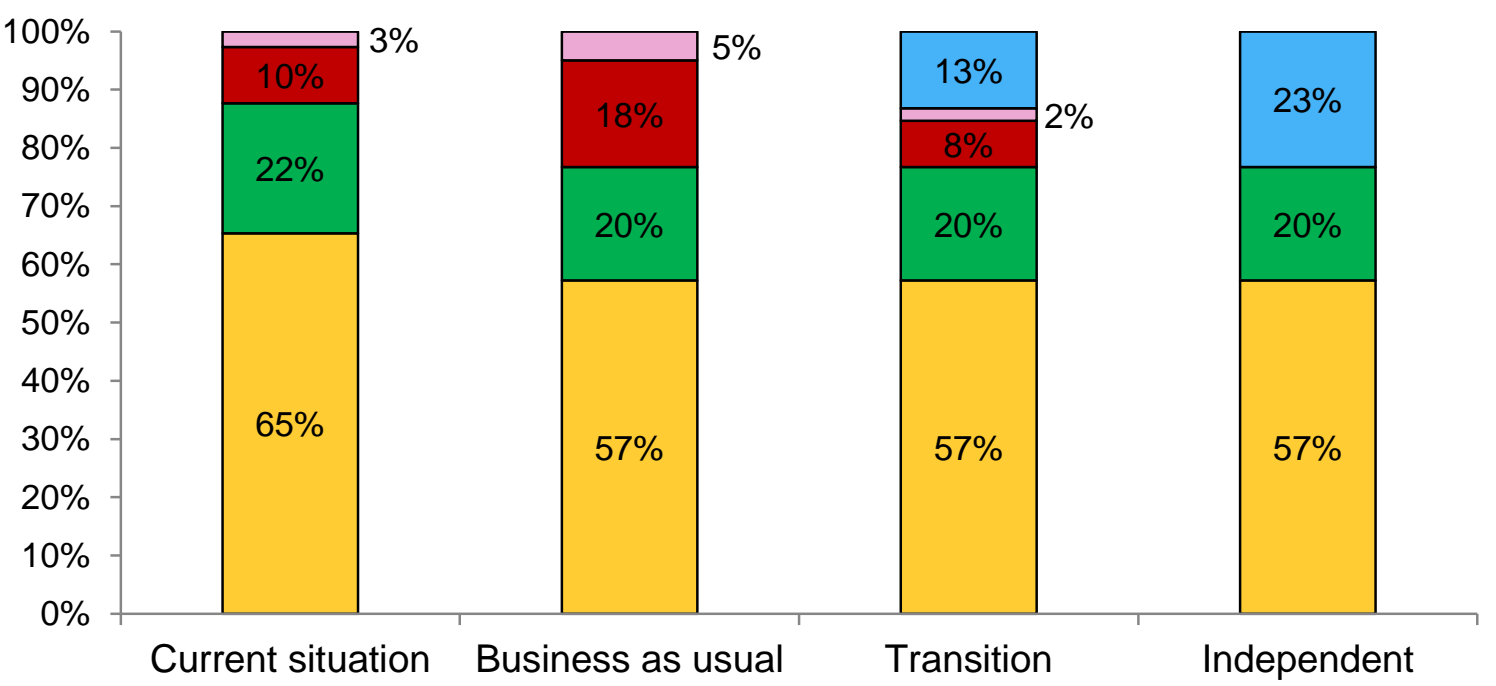

Figure 6. Water supply mix for the current situation and future scenarios

The Independent scenario assumes community self-sufficiency, with utility sectors operating independently of external fuel and water resources. In this scenario, diesel generators and LPG are phased out, with the entire electricity supply relying on the renewables. Battery storage is introduced to mitigate the intermittency of supply by solar PV and wind. Li-ion batteries are selected as they need less frequent replacement [39] and have lower environmental impacts than lead acid batteries [32]. Kerosene and imported water are no longer used either, with the resulting cooking fuel and water supply mix given in Figure 5 and Figure 6, respectively.

The hourly electricity supply in the scenarios has been simulated and cost-optimised in HOMER based on the data in Table 2 and Table 3, taking into account the increase in demand for cooking and water desalination in relevant scenarios. Availability of biomass in the representative community considered in the study, which can be used for either electricity production or cooking fuel, is estimated at 12,000 t/yr of crop residues and 68,000 t/yr of animal manure [40,41]. These are included in the analysis as constraints. The optimised electricity mix in each scenario is discussed in section 3.1 . 


\subsection{Life cycle costing}

The total life cycle costs of the utilities for the current situation and the future scenarios have been estimated per household as the sum of costs of the electricity, cooking fuels and water:

$L C C=L C O E+L C O H+L C O W+P C_{B W}$

where:
LCC
total life cycle cost (USD/hh·yr)
LCOE
levelised cost of electricity (USD/hh.yr)
$\mathrm{LCOH}$
levelised cost of heat for cooking (USD/hh.yr)
LCOW
levelised cost of locally-produced water (USD/hh·yr)
$\mathrm{PC}_{\mathrm{BW}}$
annual purchase costs of imported bottled water (USD/hh·yr).

The levelised costs of different utilities are equal to the sum of annualised capital, operating and maintenance cost of each technology providing each utility type:

$L C O E=\sum_{j \in E} x_{j}\left(A C C_{j}+O M C_{j}\right) \times \frac{E C_{h h}}{E S}$
$L C O H=\sum_{j \in C} x_{j}\left(A C C_{j}+O M C_{j}\right) \times \frac{C F C_{h h}}{C F S}$
$L C O W=\sum_{j \in W} x_{j}\left(A C C_{j}+O M C_{j}\right) \times \frac{W C_{h h}}{W S}$

where:

ACC $_{\mathrm{j}} \quad$ annualised capital costs of technology/option $j$ (USD/yr)

$\mathrm{OMC}_{\mathrm{j}} \quad$ operating and maintenance costs of technology $j$ (USD/yr)

$x_{j} \quad$ share of technology/option $j$ in the supply mix (-)

$\mathrm{E} \quad$ set of electricity generation components

$E_{\mathrm{hh}} \quad$ annual electricity consumption per household $(\mathrm{kWh} / \mathrm{hh} \cdot \mathrm{yr})$

ES total electricity consumption by the community $(\mathrm{kWh} / \mathrm{yr})$

$\mathrm{C}$ set of cooking fuels

$\mathrm{CFC}_{\mathrm{hh}} \quad$ annual cooking heat consumption per household $(\mathrm{MJ} / \mathrm{hh} \cdot \mathrm{yr})$

CFS total cooking heat consumption of by the community (MJ/yr)

W set of water supply options

$W_{\mathrm{hh}} \quad$ annual water consumption per household $\left(\mathrm{m}^{3} / \mathrm{hh} \cdot \mathrm{yr}\right)$

WS total water consumption by the community $\left(\mathrm{m}^{3} / \mathrm{yr}\right)$.

Capital costs comprise purchase, transport and installation of infrastructure and are annualised using a discount rate of $10 \%$, commonly used for energy systems in non-OECD countries [42]:

$A C C_{j}=C C_{j} \times \frac{i(1+i)^{n}}{(1+i)^{n}-1}$

where:

$\mathrm{CC}_{\mathrm{j}} \quad$ capital costs of technology $j$ (USD)

$i \quad$ discount rate

$n \quad$ lifetime of technology $j(\mathrm{yr})$.

The operating and maintenance costs include both fixed and variable maintenance expenses as well as fuel costs:

$O M C_{j}=F C_{j}+V C_{j}+f C_{j}$

where:

$\mathrm{FC}_{\mathrm{j}}$

$V C_{j}$

annual fixed costs of technology/option $j$ (USD/yr)

$\mathrm{fC}_{\mathrm{j}}$ annual variable costs of technology/option $j$ (USD/yr)

fuel costs of technology/option $j$ (USD/yr). 
For the water supply, purchase costs of imported bottled water $\left(\mathrm{PC}_{\mathrm{BW}}\right.$ in eq. (1)) are accounted for separately from the capital and operating costs since the community is not responsible for the production facilities of bottled water.

Data used for the economic analysis are summarised in Table 4. They have been sourced from own estimates and modelling in HOMER as well as from the literature. The latter have been selected to correspond to small-scale installations and rural developing countries. Future costs of power technologies and fuels have been estimated based on learning curves and market outlooks [43-46]. For consistency, all costs are expressed in 2015 US dollars (USD).

Table 4. Cost data

\begin{tabular}{|c|c|c|c|}
\hline Item & Cost $^{a}$ & Value & Reference \\
\hline \multirow[t]{5}{*}{ Diesel generator } & Capital costs (USD/kW) & 650 & Lazard [47] \\
\hline & Operating costs: fixed (USD/kW·yr) & 10 & Lazard [47] \\
\hline & Operating costs: variable (USD/kWh) & 0.01 & Lazard [47] \\
\hline & Fuel costs $(2015$, USD/L) & 0.92 & IndexMundi [48] \\
\hline & Fuel costs (2030, USD/L) & 2.12 & OECD/IEA [43] \\
\hline \multirow[t]{2}{*}{ Solar PV } & Capital costs $(2030, \mathrm{USD} / \mathrm{kW})$ & 1,088 & Lazard [47], IRENA [44] \\
\hline & Operating costs (2030, USD/kW'yr) & 14 & Lazard [47] \\
\hline \multirow[t]{2}{*}{ Wind turbine } & Capital costs $(2030$, USD $/ \mathrm{kW})$ & 3,496 & Orrell [49], IRENA [44] \\
\hline & Operating costs (2030, USD/kWhyr) & 0.03 & IRENA [50] \\
\hline \multirow{4}{*}{$\begin{array}{l}\text { Anaerobic digestion } \\
\text { (for electricity) }\end{array}$} & Capital costs (2030, USD/kW) & 1,660 & IRENA [51] \\
\hline & Operating costs: fixed (2030, USD/kW'yr) & 166 & IRENA [42] \\
\hline & Operating costs: variable (2030, USD/MWh) & 4.5 & IRENA [42] \\
\hline & Feed costs (USD/t) & 0.05 & Own calculations \\
\hline \multirow[t]{2}{*}{ Li-ion battery } & Capital costs (2030, USD/kWh) & 341 & Lazard [52], IRENA [45] \\
\hline & Operating costs (2030, USD/kWhyr) & 25 & IRENA [39] \\
\hline System converter & Capital costs $(2030$, USD/kW) & 180 & IRENA [44] \\
\hline \multirow[t]{4}{*}{ Cooking stove } & Capital cost: biogas (USD) & 48 & Afrane et al. [53] \\
\hline & Capital cost: electric (USD) & 34 & Afrane et al. [53] \\
\hline & Capital cost: LPG (USD) & 25 & Afrane et al. [53] \\
\hline & Capital cost: kerosene and solid biomass (USD) & 20 & $\begin{array}{l}\text { Wilson et al. [54], Jana } \\
\text { et al. [55] }\end{array}$ \\
\hline \multirow{4}{*}{$\begin{array}{l}\text { Anaerobic digestion } \\
\text { (for cooking fuel) }\end{array}$} & Capital costs (2030, USD, $8 \mathrm{~m}^{3}$ capacity) & 540 & Baron [56] \\
\hline & Operating costs (2030, USD/yr) & 14.31 & IRENA [42] \\
\hline & Feed costs (USD/t) & 10.91 & Own calculations \\
\hline & Digestate selling price (USD/t) & 11.26 & Own calculations \\
\hline \multirow[t]{7}{*}{ Cooking fuel } & Charcoal (USD/kg) & 0.16 & Afrane et al. [53] \\
\hline & Fuel wood (USD/kg) & 0.05 & Afrane et al. [53] \\
\hline & Crop residues (USD/t) & 10.44 & Own calculations \\
\hline & LPG (2015, USD/L) & 0.10 & IndexMundi [48] \\
\hline & LPG (2030, USD/L) & 0.28 & OECD/IEA [43][43,48] \\
\hline & Kerosene (2015, USD/L) & 0.26 & IndexMundi [48] \\
\hline & Kerosene (2030, USD/L) & 0.72 & OECD/IEA [43] \\
\hline Water well & Capital costs (USD) & 10,705 & $\begin{array}{l}\text { Marchionni et al. [57], } \\
\text { Towler and Sinnott [58] }\end{array}$ \\
\hline \multirow[t]{2}{*}{ Water pump } & Capital costs (USD) & 14,979 & Towler and Sinnott [58] \\
\hline & Operating costs $\left(\mathrm{USD} / \mathrm{m}^{3}\right)$ & 0.05 & Towler and Sinnott [58] \\
\hline \multirow[t]{3}{*}{ Desalination plant } & Capital costs: reverse osmosis module (USD) & 4,756 & $\begin{array}{l}\text { Banat and Jwaied [59], } \\
\text { Kosmadakis et al. [60], } \\
\text { Gara and Joshi [61] }\end{array}$ \\
\hline & Capital costs: balance of system (USD) & 26,949 & Papapetrou et al. [62] \\
\hline & Operating costs $\left(\mathrm{USD} / \mathrm{m}^{3}\right)^{\mathrm{b}}$ & 0.20 & $\begin{array}{l}\text { Shahabi et al. [63], } \\
\text { Ettouney et al. [64] }\end{array}$ \\
\hline Imported water & $\begin{array}{l}\text { Price: } 1.5-\mathrm{L} \text { bottled water }\left(\mathrm{USD} / \mathrm{m}^{3}\right) \\
\text { Price: } 18.9-\mathrm{L} \text { water }\left(\mathrm{USD} / \mathrm{m}^{3}\right)\end{array}$ & $\begin{array}{r}342 \\
46\end{array}$ & $\begin{array}{l}\text { DTI [65] } \\
\text { Philippine Primer [66] }\end{array}$ \\
\hline
\end{tabular}

a If no year is specified, the costs are the same for the current situation and the future scenario.

${ }^{\mathrm{b}}$ Not including cost of electricity, which is estimated through HOMER simulations for each scenario (see section 3.1 ). 
Table 5. An overview of inventory data and sources for different components of the synergen system

\begin{tabular}{|c|c|c|c|}
\hline Technology & Infrastructure & Operation and maintenance & Fuel \\
\hline Solar photovoltaics & $\begin{array}{l}\text { Multi-Si wafer, } 155.9 \mathrm{Wp} / \mathrm{m}^{2} \text { [67], ground-mounted } \\
\text { installation [68] }\end{array}$ & $20 \mathrm{~L} / \mathrm{m}^{2}$ water for cleaning [69] & - \\
\hline Wind turbine & $100-\mathrm{kW}$ onshore installation [70] & $0.04 \mathrm{~kg} / \mathrm{kWh}$ lubricating oil [69] & - \\
\hline Diesel generator & Material composition from Benton et al. [71], scaled ${ }^{a}$ & Emissions from Ecoinvent [69] & $\begin{array}{l}\text { Diesel refining [69] and transportation } \\
\text { [32] }\end{array}$ \\
\hline Li-ion battery & $\mathrm{LiMn}_{2} \mathrm{O}_{4}$ cathode and graphite anode [72] & - & \\
\hline System converter & $2.5-\mathrm{kW}$ units [68] & - & - \\
\hline Biomass gasification & $\begin{array}{l}\text { Gasifier scaled down to } 18 \mathrm{~kW} \text { from Adams [73] , coupled } \\
\text { with gas turbine [69] }\end{array}$ & Yield from Aberilla et al. [74], emissions from Ecoinvent [69] & Rice and coconut residues [74] \\
\hline Anaerobic digestion & $\begin{array}{l}8 \mathrm{~m}^{3} \text { home biogas system [56], coupled with gas turbine } \\
\text { [69] for electricity generation }\end{array}$ & Yield from Aberilla et al. [74], emissions from Ecoinvent [69] & Manure from livestock [74] \\
\hline LPG/kerosene cooking & Gas stove $[75]$ & Emissions from Singh et al. [76], 46-57\% stove efficiency [77] & $\begin{array}{l}\text { Petroleum refining [69] and } \\
\text { transportation [78] }\end{array}$ \\
\hline Solid biomass cooking & Berkeley-Darfur stove [54] & Emissions from Singh et al. [76], 11-25\% stove efficiency [77] & $\begin{array}{l}\text { Fuel wood, charcoal [76], rice and } \\
\text { coconut residues [74] }\end{array}$ \\
\hline Biogas cooking & Gas stove [75] & Emissions from Singh et al. [76], 55-57\% stove efficiency [77] & Biogas from anaerobic digestion \\
\hline Electric cooking & Electric stove [75] & $59-80 \%$ stove efficiency [77] & - \\
\hline Ground water extraction & Tube well and pump [79] & $0.35 \mathrm{kWh} / \mathrm{m}^{3}$ [79], chlorine tablets for disinfection [69] & - \\
\hline Surface water extraction & Water tank [79] & Chlorine tablets for disinfection [69] & - \\
\hline Desalination & Based on $13.5 \mathrm{~m}^{3} / \mathrm{d}$ capacity [80] & 4.17 kWh $/ \mathrm{m}^{3}$ [81], chemicals for maintenance [63] & - \\
\hline Bottled water (1.5-L bottle) & Pumping station operating on-grid [69] & Operation of pumping station [69] and bottling [82] & - \\
\hline Bottled water (18.9-L bottle) & Pumping station operating on-grid [69] & $\begin{array}{l}\text { Operation of pumping station [69], bottling and cleaning of } \\
\text { reusable containers [82] }\end{array}$ & - \\
\hline
\end{tabular}

${ }^{a}$ The mass of materials used to construct the generator estimated as: $\mathrm{m}=101.7^{\star}$ (Installed capacity) ${ }^{0.56}$ (own calculations). 


\section{$2.5 \quad$ Life cycle assessment}

This section gives an overview of the life cycle inventory data and the impact assessment method used in the study.

\subsubsection{Life cycle inventory}

An overview of the inventory data and their sources is provided in Table 5 for each technology and utility. These data have been used to model the utility systems in the current situation and future scenarios in $\mathrm{GaBi}$ ts 7.3 [83], supported by background data from ecoinvent 3.1 [69]. The system has been credited for displacing mineral fertilisers by ash from biomass and digestate from anaerobic digestion [74]. Further details on the individual technologies can be found in Aberilla et al. $[32,74,78]$ and Aberilla [81]; the focus here is on their synergistic integration to consider the impacts at present and in the future scenarios.

\subsubsection{Life cycle impact assessment}

Life cycle environmental impacts have been estimated applying the ReCiPe $1.08(\mathrm{H})$ method [84] with 18 midpoint impacts, grouped by the environmental issue they cause, as shown in Table 6 .

Table 6. Indicators for environmental sustainability assessment

\begin{tabular}{|c|c|c|}
\hline Environmental issue & Impact & Unit \\
\hline $\begin{array}{l}\text { Climate change } \\
\text { Air pollution }\end{array}$ & $\begin{array}{l}\text { Global warming potential (GWP), excluding biogenic carbon } \\
\text { Ozone depletion potential (ODP) } \\
\text { Photochemical oxidant formation potential (POFP) } \\
\text { Particulate matter formation potential (PMFP) }\end{array}$ & $\begin{array}{l}\mathrm{kg} \mathrm{CO} 2 \text { eq. } \\
\mathrm{kg} \mathrm{CFC-11} \mathrm{eq.} \\
\mathrm{kg} \mathrm{NMVOC}^{\mathrm{a}} \text { eq. } \\
\text { kg PM } \mathrm{PM}_{10} \text { eq. }\end{array}$ \\
\hline $\begin{array}{l}\text { Eutrophication and } \\
\text { acidification }\end{array}$ & $\begin{array}{l}\text { Freshwater eutrophication potential (FEP) } \\
\text { Marine eutrophication potential (MEP) } \\
\text { Terrestrial acidification potential (TAP) }\end{array}$ & $\begin{array}{l}\mathrm{kg} \mathrm{P} \text { eq. } \\
\mathrm{kg} \mathrm{N} \text { eq. } \\
\mathrm{kg} \mathrm{SO}_{2} \text { eq. }\end{array}$ \\
\hline Biodiversity & $\begin{array}{l}\text { Freshwater ecotoxicity potential (FETP) } \\
\text { Marine ecotoxicity potential (METP) } \\
\text { Terrestrial ecotoxicity potential (TETP) }\end{array}$ & $\begin{array}{l}\mathrm{kg} 1,4-D C B{ }^{b} \text { eq. } \\
\operatorname{kg} 1,4-\text { DCB }^{\mathrm{b}} \text { eq. } \\
\mathrm{kg} 1,4-\mathrm{DCB}^{\mathrm{b}}{ }^{\mathrm{e}} \text { eq. }\end{array}$ \\
\hline Resource depletion & $\begin{array}{l}\text { Fossil depletion potential (FDP) } \\
\text { Mineral depletion potential (MDP) } \\
\text { Water depletion potential (WDP) }\end{array}$ & $\begin{array}{l}\mathrm{kg} \text { oil eq. } \\
\mathrm{kg}^{3} \text { Fe eq. }\end{array}$ \\
\hline Land use & $\begin{array}{l}\text { Agricultural land occupation potential (ALOP) } \\
\text { Natural land transformation potential (NLTP) }\end{array}$ & $\begin{array}{l}\mathrm{m}^{2} \cdot \mathrm{yr} \\
\mathrm{m}^{2} \\
\mathrm{~m}^{2} \cdot \mathrm{vr}\end{array}$ \\
\hline Human health & $\begin{array}{l}\text { Human toxicity potential (HTP) } \\
\text { lonising radiation potential (IRP) }\end{array}$ & $\begin{array}{l}\operatorname{kg~1,4-DCB}{ }^{b} \text { eq. } \\
\operatorname{kg~} \mathrm{U}^{235} \text { eq. }\end{array}$ \\
\hline
\end{tabular}

${ }^{a}$ Non-methane volatile organic compounds.

b 1,4-dichlorobenzene.

To determine the total impact per functional unit (i.e. per household-year), the impact from each technology has been weighted and summed according to its contribution to the supply mix of each utility as follows:

$E I_{k, h h}=E C_{h h} \sum_{j \in E} x_{j} E l_{j, k}+C F C_{h h} \sum_{j \in C} x_{j} E l_{j, k}+W C_{h h} \sum_{j \in W} x_{j} E l_{j, k}$

where:

$E I_{k, h h}$ total annual environmental impact $k$ per household (kWh, $\mathrm{m}^{3}$ or $\mathrm{kg}$ eq.)

$\mathrm{El}_{\mathrm{j}, \mathrm{k}} \quad$ unit environmental impact $k$ from technology $\mathrm{j}$ for each utility (per kWh, MJ or $\mathrm{m}^{3}$ ).

As with the life cycle costing, the share of the cooking heat and water supply provided by each source has been obtained through the scenario definitions (section 2.3), while those for the electricity supply have been determined through simulation in HOMER. 


\section{Results and discussion}

The results of the simulation to meet the overall power demand in the current situation and future scenarios are presented in the next section. These are integrated with the scenario definitions for cooking and water in section 2.3 to obtain the overall utility supply in the different scenarios. Then, the economic and environmental impacts of the utility systems in the current situation are assessed in section 3.2. This is followed in section 3.3 by an equivalent discussion of the results for the future scenarios.

\subsection{Electricity supply in the current situation and future scenarios}

Following the synergen approach, the simulation of the current and design and cost-optimisation of future electricity systems considers both the residential demand and the electricity needed for local water supply. To meet the current demand of $95 \mathrm{kWh} / \mathrm{hh} \cdot \mathrm{yr}$ (Figure 7), a 100-kW diesel generator operating continuously $(8760 \mathrm{~h} / \mathrm{yr})$ has been sized in HOMER. As a result, 133,843 L/yr (30 $\mathrm{L} / \mathrm{hh}$ yr) of diesel is required (Table 7) in load-following operation at a mean efficiency of $33 \%$.

For the consumption of $152 \mathrm{kWh} / \mathrm{hh}$ yr electricity in the BAU scenario (Figure 7), additional dieselgenerator capacity is required, bringing the total to $300 \mathrm{~kW}$. Still operating $8760 \mathrm{~h} / \mathrm{yr}$, the generator consumes $300,724 \mathrm{~L} / \mathrm{yr}(54 \mathrm{~L} / \mathrm{hh}$ yr) of fuel (Table 7 ) at a slightly lower mean efficiency of $30 \%$, as determined by the hourly load simulation in HOMER.

Unlike the BAU, the power demand in the Transition and Independent scenarios is derived more from water production (especially desalination) than direct residential consumption). The 100-kW diesel generator is retained in the Transition scenario, but it only contributes $1 \%$ to the total power supply of $0.6 \mathrm{kWh} / \mathrm{hh}$ yr (Figure 7) as it is primarily used for peak operation. Most of the electricity $(75 \%)$ is provided by the gas turbine fed by bio-syngas from the biomass gasifier (Table 7$)$. Energy storage is not required as the gas turbine and diesel generator can balance the intermittent supply by solar PV and wind.

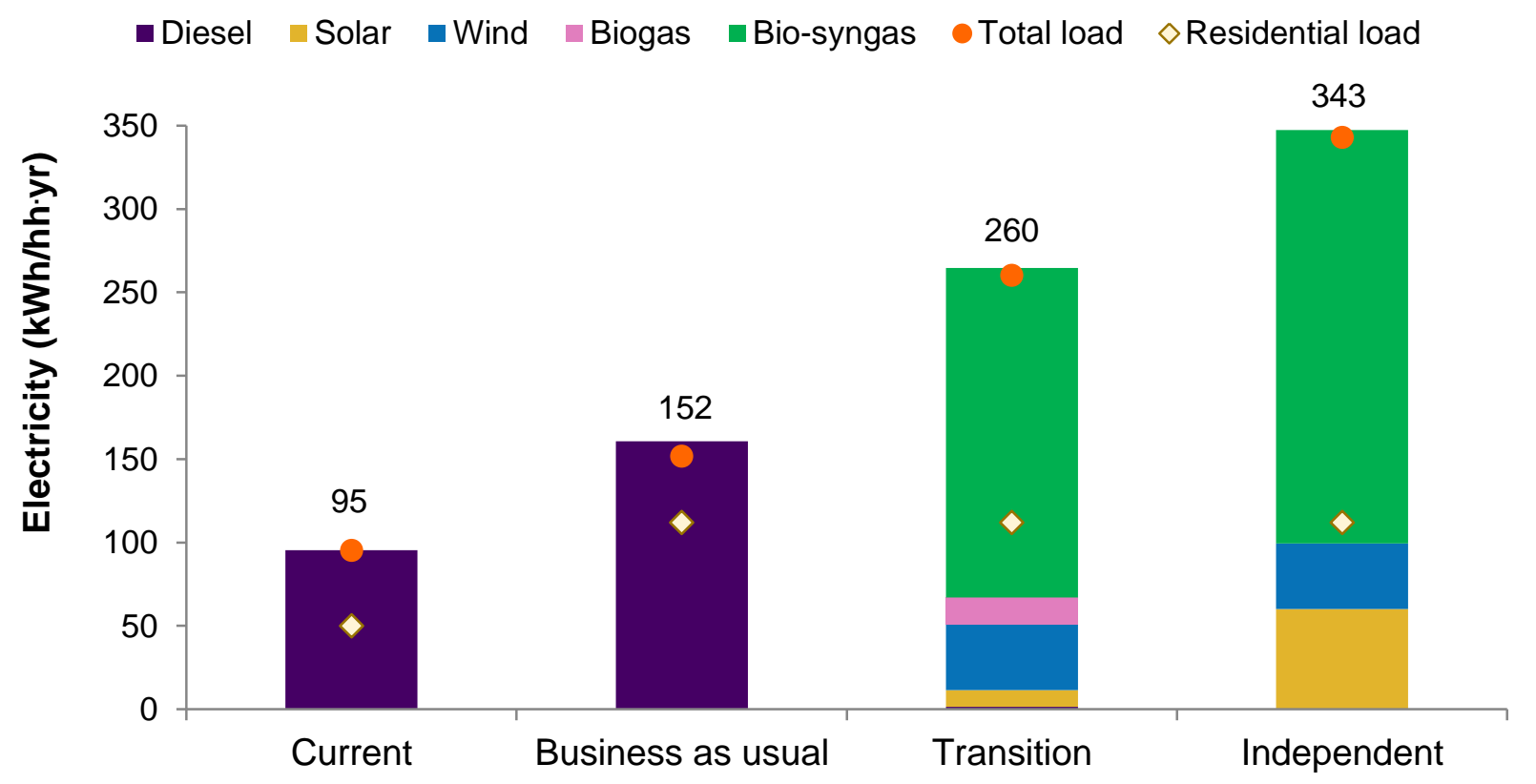

Figure 7. Electricity generation and consumption in the current situation and future scenarios (Direct residential load: electricity consumed directly by the household, including for cooking. Total load: direct residential load plus the power consumed for water production. The values shown above the bars correspond to the total load.) 
In the Independent scenario, diesel is phased out and the electricity demand of $343 \mathrm{kWh} / \mathrm{hh} \cdot \mathrm{yr}$ is supplied by solar PV, wind and biomass gasification (Figure 7). The latter is the main source of power $(71 \%)$ and solar output is more than eight times greater than in the Transition scenario. Liion battery is selected by the optimisation model as a backup for solar PV and wind turbine (Table 7).

The outputs of the simulation and optimisation of the electricity synergen system related to the infrastructure and fuel requirements have been used as an input into the LCA models to estimate the environmental impacts of electricity generation and consumption. The cost estimations have been used to determine the life cycle costs of the systems, as discussed next.

Table 7 The electricity system in the current situation and future scenarios ${ }^{a}$

\begin{tabular}{|c|c|c|c|c|}
\hline System component & Current & Business as usual & Transition & Independent \\
\hline Diesel generator $(\mathrm{kW})$ & 100 & 300 & 100 & - \\
\hline Diesel fuel (L/yr) & 133,843 & 300,724 & 2,570 & - \\
\hline Operating hours (h/yr) & 8,760 & 8,760 & 159 & - \\
\hline Solar PV (kWp) & - & - & 35.7 & 214 \\
\hline Wind turbine (kW) & - & - & 100 & 100 \\
\hline Gas turbine, anaerobic digestion (kW) & - & - & 50 & - \\
\hline Biomass fuel (t/yr) & - & - & 5,370 & - \\
\hline Operating hours (h/yr) & - & - & 2,330 & - \\
\hline Gas turbine, biomass gasification (kW) & - & - & 200 & 300 \\
\hline Biomass fuel (t/yr) & - & - & 2,335 & 2,914 \\
\hline Operating hours $(\mathrm{h} / \mathrm{yr})$ & - & - & 6,421 & 4,856 \\
\hline Li-ion battery $(\mathrm{kWh})$ & - & - & - & 194 \\
\hline Expected life (yr) & - & - & - & 15 \\
\hline System converter (kW) & - & - & 10 & 179 \\
\hline
\end{tabular}

${ }^{a}$ The results correspond to the whole community (4,534 households in the current situation and 5,588 in 2030), obtained through simulation (current situation) and design and optimisation (future scenarios) in HOMER.

\subsection{Current situation}

The economic and environmental sustainability of the current situation is evaluated below and used as a reference for comparison with the sustainability of future scenarios in section 3.3.

\subsubsection{Economic sustainability assessment}

The current annual LCC are estimated at 2,944 USD per household (Figure 8). This is largely due to the costs of imported water, which contributes $91 \%$ to the total $(2,677 \mathrm{USD} / \mathrm{hh}$ yr). Locallysourced water and cooking heat add a further $7 \%$ to the total and electricity the remaining $2 \%(220$ and 46 USD/hhyr, respectively).

Total annualised capital costs are equivalent to $107 \mathrm{USD} / \mathrm{hh} \cdot \mathrm{yr}$ (Figure 9), with $79 \%$ derived from infrastructure for local water production. The diesel generator comprises $16 \%$ of the capital investment, while cooking stoves account for $6 \%$. Operating and maintenance costs are higher at $160 \mathrm{USD} / \mathrm{hh} \cdot \mathrm{yr}$ (Figure 10), with the majority (65\%) spent on cooking fuels. Of the $30 \mathrm{USD} / \mathrm{hh} \cdot \mathrm{yr}$ operating and maintenance costs of the diesel generator, $96 \%$ is due to fuel. Electricity accounts for $78 \%$ of the operating costs of the water supply, again highlighting the interactions between the energy and water sectors.

Per unit of utility, the levelised costs of the current supply mix are $0.46 \mathrm{USD} / \mathrm{kWh}$ of electricity, 22 USD/GJ of heat for cooking, $0.63 \mathrm{USD} / \mathrm{m}^{3}$ of locally produced water and $104 \mathrm{USD} / \mathrm{m}^{3}$ of imported water (Table 8). Based on the annual consumption (functional unit) this amounts to the abovementioned total LCC of 2,944 USD/hhyr with imported water and $267 \mathrm{USD} / \mathrm{hh}$ yr without it. The latter compares well with reported census data for utility expenses of four-person households in southwest Philippines (135-330 USD) [24].

For electricity and heat for cooking, the costs are driven by fuel costs, which account for $62 \%$ and $95 \%$ of the total, respectively. As indicated in Table 8, charcoal and fuel wood have the highest 
costs per heat provided (42.78 and 33.65 USD/GJ, respectively) due to the low stove efficiencies. The cheapest fuel is crop residues at 7.17 USD/GJ.

For water, the largest unit cost is for imported bottled water: $46 \mathrm{USD} / \mathrm{m}^{3}$ for $18.9-\mathrm{L}$ containers and $342 \mathrm{USD} / \mathrm{m}^{3}$ for $1.5-\mathrm{L}$ bottles (Table 8 ). This is 3-4 orders of magnitude more expensive than surface or ground water: 0.34 and $0.80 \mathrm{USD} / \mathrm{m}^{3}$, respectively (including the cost of electricity). Purchase costs increase the life cycle cost of water supply to $14.15 \mathrm{USD} / \mathrm{m}^{3}$. Despite the high cost of bottled water, its consumption can be significant in households, regardless of income or availability of tap water $[85,86]$. Negative public perceptions of the safety of tap water and trustworthiness of water supplies are commonly-identified drivers for bottled water consumption [86]. In addition, bottled water can also be brought into remote communities as part of disaster relief efforts (e.g. in response to typhoons [87]); hence, the costs may not be fully borne by the residents. For context, 1,586 recorded natural disasters in Southeast Asia affected over 3.4 million households in 2018 [88].

Table 8. Current levelised and annual costs of the utilities by source

\begin{tabular}{|c|c|c|c|}
\hline Utility & Levelised cost & Annual consumption ${ }^{a}$ & $\begin{array}{c}\text { Annual costs } \\
\text { (USD/hhyr) }\end{array}$ \\
\hline \multicolumn{4}{|l|}{ Electricity } \\
\hline Diesel & 0.46 USD/kWh & 100 kWh/hhyr & 46 \\
\hline \multicolumn{4}{|l|}{ Heat for cooking } \\
\hline LPG & 10.21 USD/GJ & 1,937 MJ/hhyr & 20 \\
\hline Kerosene & 18.11 USD/GJ & $215 \mathrm{MJ} / \mathrm{hh} y \mathrm{r}$ & 4 \\
\hline Charcoal & 42.78 USD/GJ & $745 \mathrm{MJ} / \mathrm{hh} y \mathrm{r}$ & 32 \\
\hline Fuel wood & 33.65 USD/GJ & $1505 \mathrm{MJ} / \mathrm{hh} y \mathrm{r}$ & 51 \\
\hline Crop residues & 6.92 USD/GJ & $465 \mathrm{MJ} / \mathrm{hh} \cdot \mathrm{yr}$ & 3 \\
\hline Total $p^{p}$ & 22.48 USD/GJ & 4.867 MJ/hhyr & 109 \\
\hline \multicolumn{4}{|l|}{ Water } \\
\hline Groundwater & $0.80 \mathrm{USD} / \mathrm{m}^{3}$ & $129 \mathrm{~m}^{3} / \mathrm{hh} \mathrm{yr}$ & 98 \\
\hline Surface water & $0.34 \mathrm{USD} / \mathrm{m}^{3}$ & $44 \mathrm{~m}^{3} / \mathrm{hh} y \mathrm{r}$ & 13 \\
\hline Total local water ${ }^{b}$ & $0.63 U S D / m^{3}$ & $173 \mathrm{~m}^{3} / \mathrm{hhyr}$ & 111 \\
\hline Bottled water $(18.9 \mathrm{~L})^{\mathrm{c}}$ & $45.97 \mathrm{USD} / \mathrm{m}^{3}$ & $19 \mathrm{~m}^{3} / \mathrm{hh} y \mathrm{r}$ & 880 \\
\hline Bottled water $(1.5 \mathrm{~L})^{\mathrm{c}}$ & $342.40 \mathrm{USD} / \mathrm{m}^{3}$ & $5 \mathrm{~m}^{3} / \mathrm{hhyr}$ & 1797 \\
\hline Total imported water ${ }^{p}$ & $104.49 \mathrm{USD} / \mathrm{m}^{3}$ & $24 \mathrm{~m}^{3} / \mathrm{hhyr}$ & 2.677 \\
\hline Total water ${ }^{\circ}$ & $14.04 \mathrm{USD} / \mathrm{m}^{3}$ & $197 \mathrm{~m}^{3} / \mathrm{hhyr}$ & 2,789 \\
\hline Total annual life cycle cost & & & 2,944 \\
\hline
\end{tabular}

a Based on the functional unit, i.e. annual consumption of $100 \mathrm{kWh}$ electricity, 4.87 GJ heat for cooking and 197 $\mathrm{m}^{3}$ water per household.

${ }^{\mathrm{b}}$ Based on the share of different fuels and water sources, respectively (see Figure 5 and Figure 6).

${ }^{\circ}$ Purchase cost of imported water.

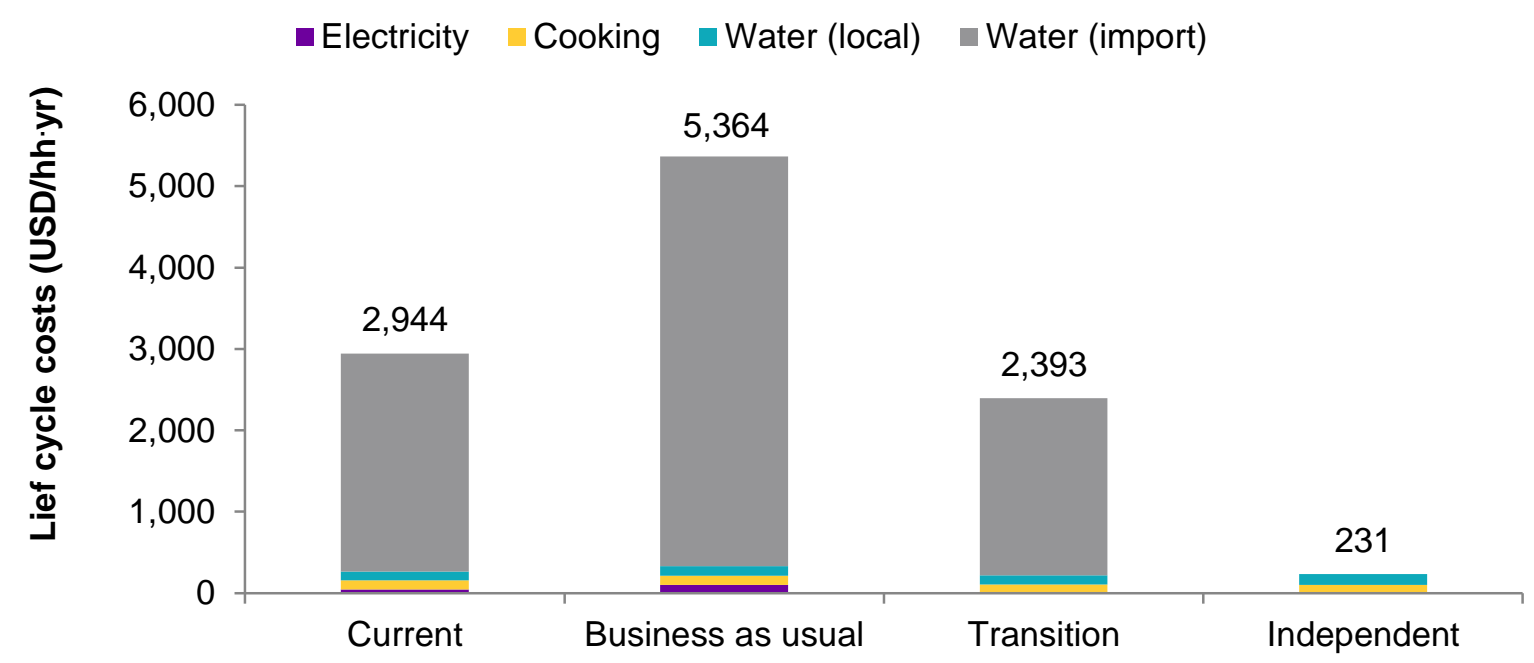

Figure 8. Annual life cycle costs per household for the current situation and future scenarios 


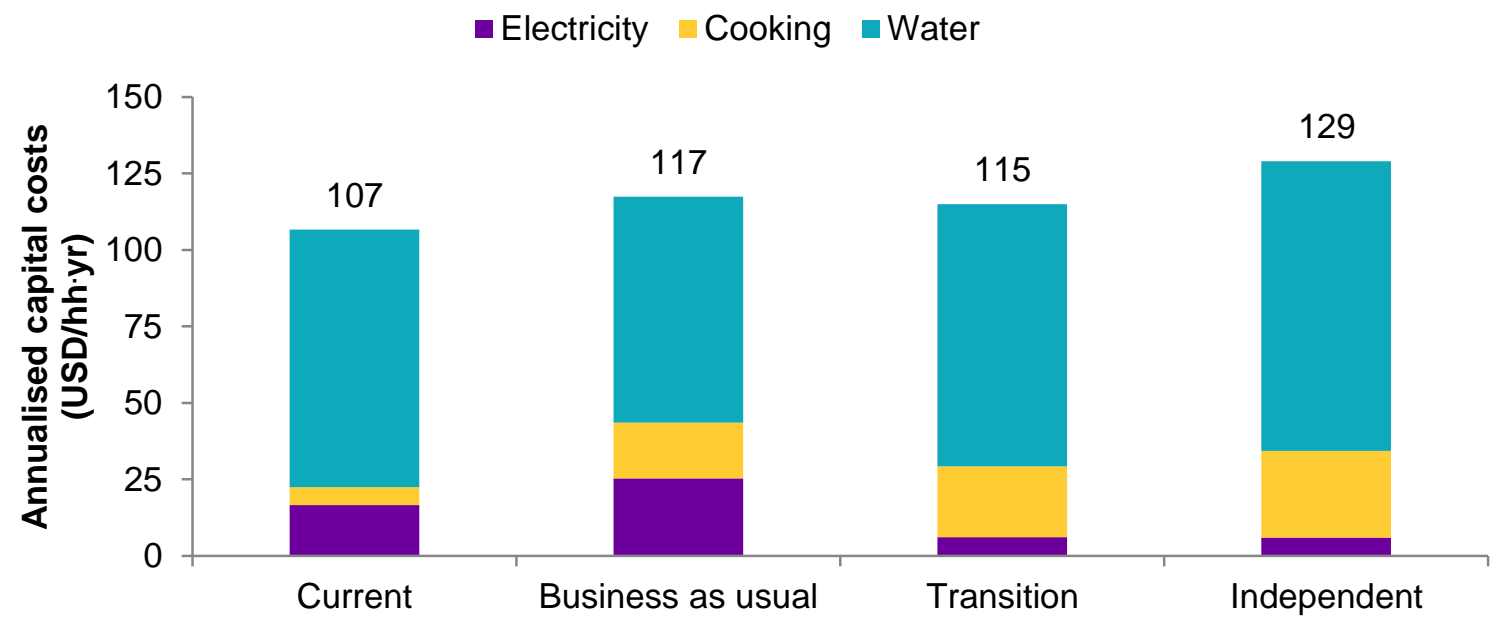

Figure 9. Annualised capital costs per household for the current situation and future scenarios

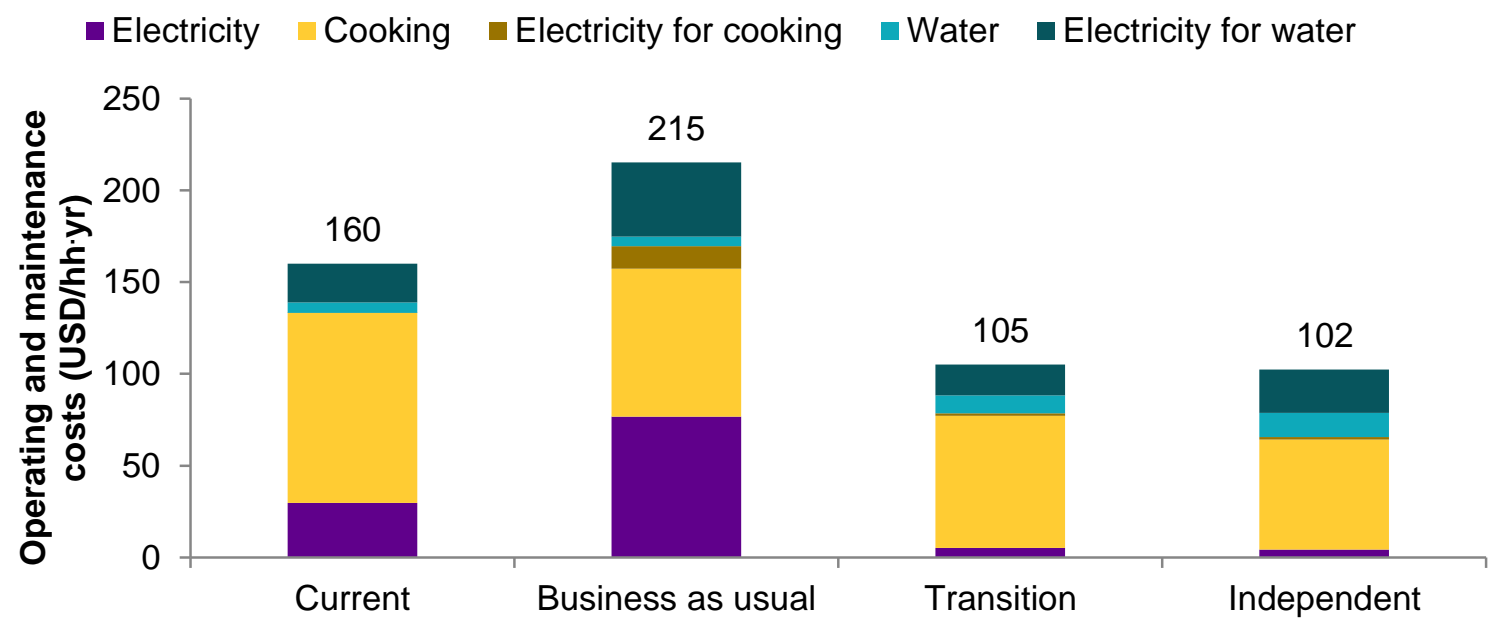

Figure 10. Operating and maintenance costs per household for the current situation and future scenarios

\subsubsection{Environmental sustainability assessment}

The total annual environmental impacts of the current synergen system are shown in Figure 11; the breakdown by utility can be found in Tables S1-S3 in the Supplementary Information (SI). In 13 out of the 18 environmental categories, water provision contributes more than half of the total impacts per household (Figure S1). This is primarily due to the production of $1.5 \mathrm{~L}$ bottles. Despite being completely sourced from fossil fuels, power consumption contributes only $0.5-13 \%$ to the impacts.

The total GWP is estimated at $1.7 \mathrm{t} \mathrm{CO}_{2}$-eq./hh-yr, with $51 \%$ attributed to the water in 1.5 - $\mathrm{L}$ bottles. At $1 \mathrm{t} \mathrm{CO}$-eq. $/ \mathrm{kWh}$ and consumption of $100 \mathrm{kWh} / \mathrm{hh} \cdot \mathrm{yr}$, electricity contributes $6 \%$ to the total impact of the synergen system. Power required for the water supply $\left(0.23 \mathrm{kWh} / \mathrm{m}^{3}\right)$ adds a further $2.7 \%$. The average GWP of the cooking fuel mix is $142 \mathrm{~g} \mathrm{CO}_{2}$-eq./MJ, with $67 \%$ of the impact occurring at the point of use. Fuel processing and collection cause $31 \%$ of the GWP of cooking, and the stoves the remaining $2 \%$. Therefore, imported water and cooking fuels are the hotspots for this impact.

The system has a WDP of $10.4 \mathrm{~m}^{3} / \mathrm{m}^{3}$ or $2,229 \mathrm{~m} / \mathrm{hh} \cdot \mathrm{yr}$. Since a household consumes only 197 $\mathrm{m}^{3} / \mathrm{yr}$ of water, $91 \%$ of WDP is embedded or virtual water. Most of the embedded water is derived from the manufacture of plastic bottles. Looking at each utility, the WDP of electricity is 0.25 $\mathrm{m}^{3} / \mathrm{kWh}$ while that of heat for cooking is $32 \mathrm{~L} / \mathrm{MJ}$. Scaling up to the household level, these only contribute $1 \%$ and $7 \%$ to the total, respectively. 

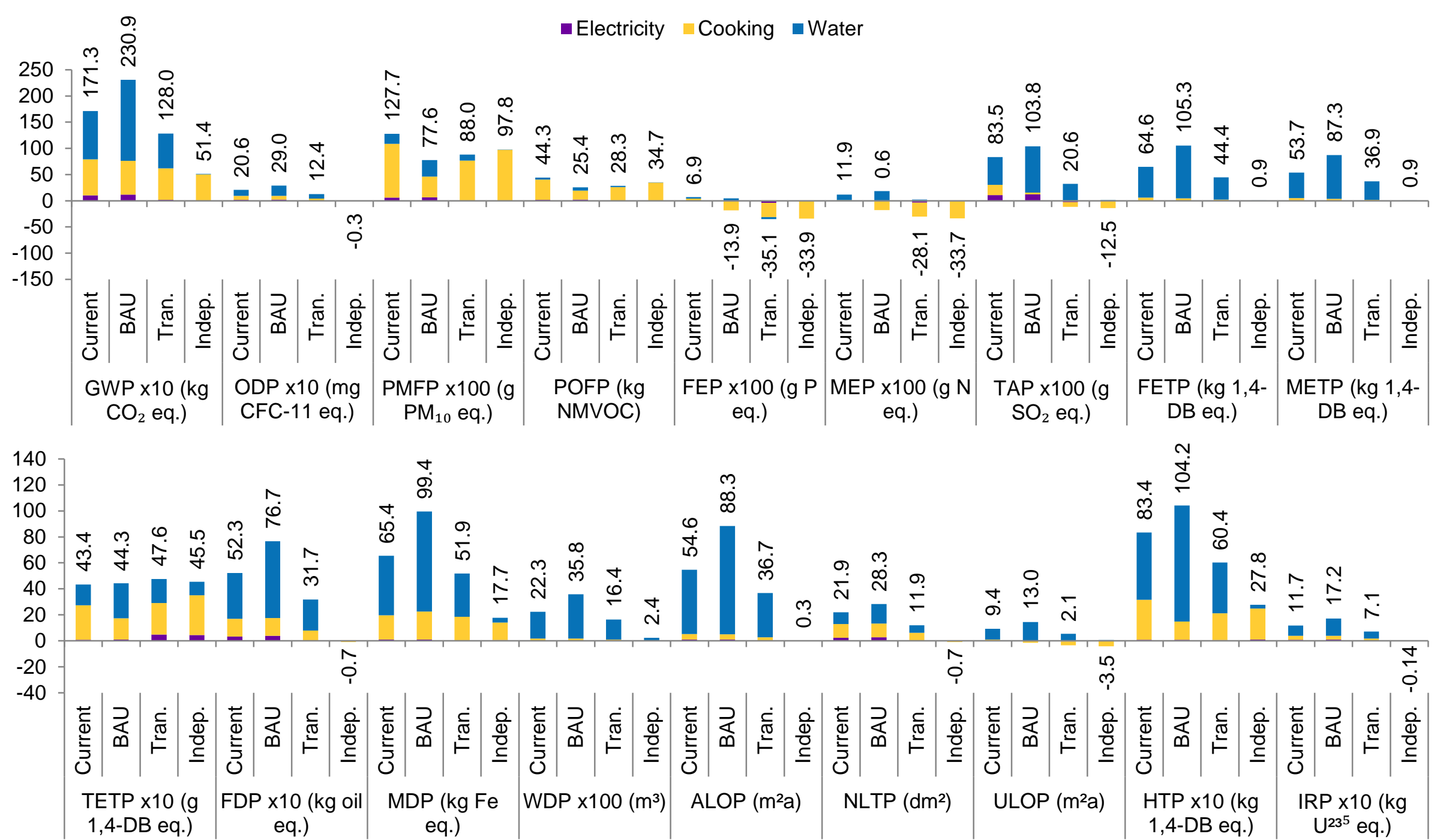

Figure 11. Annual environmental impacts per household for the current situation and future scenarios

[All impacts are expressed per household per year. BAU: Business as usual; Tran.: Transition; Indep.: Independent. For the impacts nomenclature, see Table 6] 
As mentioned above, direct residential consumption of electricity has a relatively small contribution to the impacts. An exception is TAP (13\% contribution) due to $\mathrm{SO}_{2}$ emissions from combustion of diesel. Electricity is also used in local water production, although its impacts are lower than those from imported water. Within the water supply chain, electricity has the highest contributions to POFP (20\%) and PMFP (14\%).

The cooking fuels are the greatest contributors to PMFP and POFP ( $80 \%$ and $87 \%$, respectively), primarily due to emissions of particulates from combustion of solid biomass fuels (for PMFP) and non-methane volatile organic compounds (NMVOC) from charcoal production. Cooking fuels also cause most of FEP and TETP (61\%). Both are mainly due to the disposal of ash from solid biomass fuels to soil.

The water supply contributes $>90 \%$ to water ecotoxicity (FETP and METP) and land occupation (ALOP and ULOP). These are again due to the bottles, with additional impacts from bottle cleaning (ecotoxicity) and paper labels (land occupation). The impacts of the current situation are discussed further in comparison with the future scenarios in section 3.3.1.2.

\subsection{Future scenarios}

This section starts with a discussion of the economic sustainability of the future scenarios, providing a breakdown of different costs. This is followed by a detailed discussion of different environmental impacts to determine the environmental sustainability of the future scenarios.

\subsubsection{Economic sustainability assessment}

\subsubsection{Total life cycle costs (LCC)}

As shown in Figure 8 and Table 9, the Independent scenario has the lowest and BAU the highest LCC: 231 and 5,364 USD/hhyr, respectively. The former is nearly 13 times lower than at present due to the absence of imported fuels and water and reduced levelised costs of electricity $(0.10$ USD/kWh), cooking fuels (18 USD/GJ) and water $\left(0.67 \mathrm{USD} / \mathrm{m}^{3}\right)$. The non-generating components of the power system, i.e. battery storage and system converter, represent $9 \%$ of the total LCC of electricity (0.79 and $0.18 \mathrm{USD} / \mathrm{hh} \cdot \mathrm{yr}$, respectively; Table 9).

The BAU scenario has $82 \%$ higher LCC than currently. With a forecasted increase in diesel price, as well as higher dependence on diesel power and imported water, the levelised cost of electricity is more than twice as expensive (1.02 USD/kWh) and the levelised cost of water is $85 \%$ higher in the BAU scenario than at present (Table 9). It can also be noted that the LCC in the BAU scenario represent $90 \%$ of the current national average household income in the Philippines $(5,912$ USD/yr [24]), making it unsuitable for remote communities.

The LCC in the Transition scenario are 19\% lower than the present $(2,393 \mathrm{USD} / \mathrm{hh} \cdot \mathrm{yr})$, resulting from a $12-76 \%$ decrease in levelised costs. Specifically, the cost of electricity reduces to 0.11 USD/kWh, of cooking to $20 \mathrm{USD} / \mathrm{GJ}$ and of water to $12 \mathrm{USD} / \mathrm{m}^{3}$ (Table 9). This is largely due to the absence of imported fuels (diesel and LPG) and the adoption of biogas for cooking.

As in the current situation, the water supply is overwhelmingly the main contributor to the total LCC $(>95 \%)$ in the BAU and Transition scenarios (Figure 8$)$. This is almost solely due to the costs of imported water (95-97\%). The water supply also represents the majority (57\%) of the costs in the Independent scenario, despite the self-sufficiency in water (and energy).

Therefore, these results suggest that self-sufficient utility systems in remote communities are financially attractive but will require adoption of new technologies, such as seawater desalination, biomass gasification and anaerobic digestion, to replace imported energy and water supply. 
Table 9. Levelised and annual costs of the utilities for the future scenarios

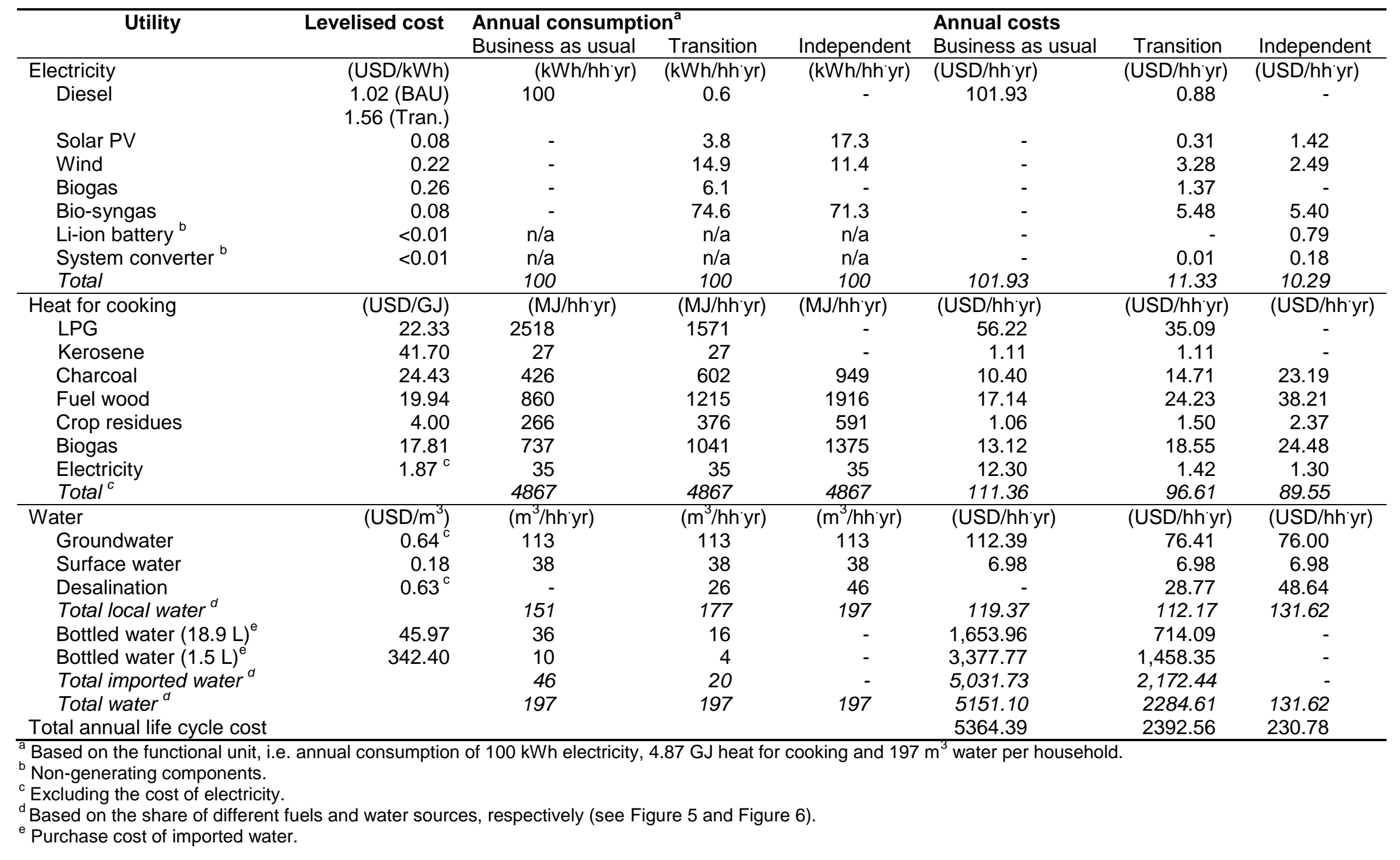




\subsubsection{Annualised capital costs (ACC)}

Capital expenditure in the future scenarios is $8-21 \%$ higher than at present (107 USD/hh.yr), with the Independent scenario having the highest costs (129 USD/hh·yr). Water supply is responsible for $63-75 \%$ of the total ACC (Figure 9) and the most significant cost items include the infrastructure for wells, pipes and desalination modules (Table 4). The equivalent capital costs of the power system (25 USD/hh·yr) in the BAU scenario are 53\% greater than at present since a proportional increase in generator capacity is needed. Capital costs are also $21 \%$ higher in the Independent scenario than currently due to the high costs of solar PV panels and wind turbines. Capital investment for provision of cooking heat at least trebles in the future scenarios, mainly due to the infrastructure for biogas production. In addition, introduction of new fuel types to the mix requires installation of their corresponding stoves.

\subsubsection{Operating and maintenance costs (OMC)}

The Independent scenario has the lowest OMC and BAU the highest: 102 and $215 \mathrm{USD} / \mathrm{hh} \cdot \mathrm{yr}$, respectively (Figure 10). The Transition scenario is close to the Independent (105 USD), both of which have significantly lower costs than at present (160 USD). Across the scenarios, more than $59 \%$ of the OMC is attributed to cooking due to costs of charcoal and fuel wood. An exception is the BAU scenario where cooking fuels have somewhat lower contribution due to a greater relative influence of the electricity cost. The latter is due to the increased use of diesel, which constitutes $36 \%$ of the electricity cost. Electricity used for cooking in the future scenarios is minimal, although it is responsible for $13 \%$ of the cooking OMC in the BAU scenario. While the OMC of electricity and cooking are lower in the Transition and Independent scenarios than at present, the OMC for water increases by $1-37 \%$. This is due to the chemicals and electricity used for desalination. The waterenergy nexus is also reflected in the economic analysis as electricity contributes $63-89 \%$ of the water sector's OMC across all scenarios.

\subsubsection{Environmental sustainability assessment}

The results of the environmental sustainability assessment for the three scenarios are summarised in Figure 11 in comparison with the current situation; further details for each utility can be found in Tables S1-S3 the SI. The Independent scenario is the best option which has the lowest impacts in 14 categories. By contrast, BAU is the worst alternative with 13 highest impacts. The Transition scenario has the highest TETP, while all future scenarios have better environmental performance in air pollution (PMFP and POFP) and eutrophication (FEP and MEP) than the current situation. Further discussion of the results is provided in the next section.

\subsubsection{Climate change (GWP)}

The BAU scenario has 35\% higher GWP than the current situation (2.31 vs $1.71 \mathrm{t} \mathrm{CO}_{2}$-eq./hh.yr), with $67 \%$ of the impact attributed to the water sector due to the increased purchases of bottled water. The Transition and Independent scenarios have 25\% and 70\% lower GWP than at present. The introduction of renewables in these scenarios, especially bioenergy from gasification and anaerobic digestion, reduces significantly the GWP of power production: by $85 \%$ in Transition and $>100 \%$ in Independent (i.e. net credits for biomass gasification). This also has the effect of reducing the impacts of water supply, which compounded with a lower fraction of water imports, results in $28 \%$ and $99 \%$ lower GWP for the water sector, respectively.

\subsubsection{Air pollution (ODP, PMFP, POFP)}

Across the scenarios as well as in the current situation, water supply is responsible for the majority of ODP due to the $\mathrm{CCl}_{4}$ emissions associated with the production of detergents for the cleaning of reusable bottles. PMFP and POFP are mainly due to the combustion of solid biomass fuels used for cooking. The air pollution impacts decrease from their current levels in all future scenarios, except for the ODP in BAU. Generally this is due to an improved cooking fuel mix since biogas benefits from the system credits, reducing the ODP of LPG and high PMFP and POFP of solid biomass fuels. For the BAU, the ODP is $41 \%$ higher than at present as all sectors individually see an increase in this impact of $0.5-71 \%$. The PMFP and POFP of electricity and water also increase in BAU by $15-63 \%$ because of greater reliance on diesel and imported water, but are compensated by the $56-61 \%$ reductions from the cooking system resulting from a lower fraction of solid biomass. The net effect is a reduction of $39-43 \%$ compared to the current situation. Also, since BAU has the 
lowest share of solid biomass in the cooking fuel mix, it has the lowest PMFP and POFP (7.8 and $25 \mathrm{~kg} \mathrm{NMVOC/hh \cdot yr}$, respectively).

\subsubsection{Eutrophication and acidification (FEP, MEP, TAP)}

Like the previous impacts, eutrophication (FEP and MEP) is lower in the three future scenarios than at present, with net-negative impacts across the scenarios, except for MEP in the BAU which is slightly net-positive. This is driven by significant system credits related to anaerobic digestion for avoided disposal of animal manure and the use of the digestate as a fertiliser substitute. The Independent scenario has the lowest MEP while the Transition is the best option for FEP.

For acidification, LPG and imported water have high contributions to TAP from the upstream petrochemical stage in oil refining and bottle production. Hence, TAP is lower in the Transition and Independent scenarios where there is reduced consumption of LPG and imported water. This impact is net-negative for the Independent scenario due to the credits for utilisation of manure for biogas used for cooking. By the same logic, the TAP of the BAU scenario is $24 \%$ higher than the current impact due to higher share of LPG and imported water.

\subsubsection{Ecotoxicity (FETP, METP, TETP)}

FETP and METP are $63 \%$ higher in the BAU scenario than presently (105 and 87 vs 65 and $54 \mathrm{~kg}$ 1,4-DB eq./hh.yr, respectively), with $96 \%$ of the impacts derived from the water supply. The higher amount of imported water in this scenario leads to additional ecotoxicity associated with the production and cleaning of bottles. The water supply is also the highest contributor to FETP and METP in the Transition and Independent scenarios, although in this case the biogas and biosyngas credits reduce the total impacts to a net 69\% (Transition) and 2\% (Independent) compared to the current situation.

On the other hand, TETP is $2-10 \%$ higher in the future scenarios than at present. Water supply is the most significant contributor in the BAU scenario due to imported water, with a $69 \%$ higher impact than of the current water supply, mostly due to plastics manufacture. The Transition scenario has more than five times higher TETP per kWh than the current situation due to heavy metals in the ash from crop residues and digestate from anaerobic digestion. Lastly, the electricity and cooking fuel mix in Independent increase TETP by $5 \%$, also due to ash and digestate.

\subsubsection{Resource depletion (FDP, MDP, WDP)}

BAU would lead to the highest increase in resource depletion on the current situation (47-61\%) while the Independent scenario would reduce the resource dependence by $>78 \%$. FDP would also be net-negative, avoiding depletion of $7 \mathrm{~kg}$ oil eq./hh. $\mathrm{yr}$ due to the credits for the displacement of mineral fertilisers by digestate.

The Transition scenario benefits from the lower usage of LPG, kerosene and imported water as well as the credits for waste biomass-derived energy. As a result, it has $21-39 \%$ lower impacts relative to the present depletion of resources.

\subsubsection{Land use (ALOP, NLTP, ULOP)}

Land transformation and occupation in the future scenarios follow the trend of most of the previous categories: the BAU has impacts higher than the present day, while the Transition and Independent scenarios result in progressively lower impacts. The latter scenario has a net-negative ULOP, avoiding the use of $3.5 \mathrm{~m}^{2}$ annually. However, this trend is different if only electricity is considered. In the Transition scenario, electricity supply has the lowest impacts, with all three categories having net credits for waste biomass utilisation, while land occupation is higher in the Independent scenario due to the space required to install solar PV panels. However, credits from biomass gasification in the Independent scenario still lead to a net reduction in ULOP of $26 \%$ relative to the current situation.

\subsubsection{Human health (HTP, IRP)}

The BAU scenario has the highest HTP and IRP, with the impacts of electricity and water supply increasing by $11-72 \%$ compared to the current situation. However, the BAU cooking fuel mix has $54 \%$ lower HTP per MJ due to lower fractions of solid biomass. Independent is again the best 
option for both impacts. More than $62 \%$ of the impacts in all the scenarios are attributed to the water supply, except for HTP of the Independent scenario. In this case, the absence of imported water shifts the majority of the HTP contribution to the cooking fuels.

\section{Conclusions and recommendations}

This paper has quantified the economic and environmental sustainability of supplying electricity, cooking heat and water to remote communities. Both the current situation and future scenarios have been evaluated following the synergen approach developed in this work to consider synergistic interactions between the three utilities.

The current annual LCC are estimated at 2,944 USD per household, with $91 \%$ due to the imported water. The highest costs are found for BAU (5,364 USD/hh.yr), followed by the Transition scenario (2,393 USD/hh·yr), also largely due to the imported water. The Independent scenario demonstrates that a remote community can be fully sufficient in its utilities with an order of magnitude lower costs than at present (231 USD/hh-yr). However, capital investment for an independent off-grid utility system is $21 \%$ greater than today. This can pose a barrier for developing countries as investors may demand higher rates of returns to reflect the risks associated with lack of experience and instability of energy policies, as well as perceptions of technology immaturity. This risk may be mitigated through involvement of local stakeholders, demonstration of environmental and societal benefits and through appropriate policy incentives.

The Independent scenario has the lowest impacts in 14 categories while BAU is the worst alternative for 13 impacts. The Transition scenario has the highest TETP, while all future scenarios have lower PMFP and POFP and eutrophication than at present. Overall, there is no single scenario wherein all of the environmental impacts and costs are reduced compared to the current situation. However, the Transition and Independent scenarios have lower impacts than at present in almost all environmental categories and lower LCC.

The combined analysis of the three utilities carried out in this study further suggests that seawater desalination and bioenergy from residual/waste biomass can enable a sustainable transition towards self-sufficiency of remote communities as seen in the Independent scenario. Although desalination can replace imported bottled water, its sustainability is dependent on the power system that runs it. Hence, proposals for implementing desalination in remote communities are recommended to evaluate the local power system to ensure that environmental impacts are reduced. Desalination can also operate in synergy with variable renewable energy sources (e.g. solar PV and wind) to utilise excess power generated at off-peak times. While the results of this work have been obtained through hourly simulations, future work can validate these results through pilot demonstrations or integrated analysis with control systems.

Moreover, a reliable supply of waste biomass, such as crop residues and animal manure, is necessary to realise the economic and environmental benefits they offer. If bioenergy is adopted as a main source of electricity and heat for cooking in remote communities, appropriate management of the agricultural production cycle will be required to allocate biomass resources to different utility sectors. Further work is needed to determine how much of these resources are realistically harvestable on a sustainable basis. As biomass is a versatile resource for agricultural communities, supply chain optimisation can provide guidance on its optimal utilisation as a fuel, food or agricultural input.

Additionally, high dependence on a specific technology or resource can pose risks in security of supply that can affect other sectors. To broaden the sustainability assessment, consideration of energy security and other social indicators is recommended for future work. Furthermore, the synergen approach applied here could be applied to explore the sustainability implications for other climatic zones, production scales and technology options. Future studies could also investigate the application of multi-criteria decision analysis to facilitate further understanding and trade-offs between benefits and costs of future synergen systems in remote communities. 
Finally, it is recommended that community planners and local authorities should consider other aspects of household consumption in addition to electricity when devising sustainability strategies. As shown in this study, traditional cooking fuels and imported water can be greater sources of environmental impacts and costs than power generation. Development pathways that rely on currently installed technologies and supply chains (e.g. the BAU scenario) can exacerbate these impacts while increasing life cycle costs. Although new technologies may be more capitalintensive, local stakeholders can use life cycle approaches to demonstrate lower life cycle costs and encourage investment in remote communities.

\section{Acknowledgements}

This work was funded by the UK Department for Business, Energy and Industrial Strategy and the Philippine Commission on Higher Education delivered by the British Council through the CHEDNewton PhD Scholarship programme (ID 261718262), as well as by the UK Engineering and Physical Sciences Research Council (EPSRC, Gr. no. EP/K011820/1). This funding is gratefully acknowledged.

\section{References}

[1] UNDP. Sustainable Development 2017. http://www.undp.org/content/undp/en/home/sustainable-development-goals.html (accessed June 19, 2017).

[2] International Energy Agency (IEA) and the World Bank. Global Tracking Framework 2017Progress toward Sustainable Energy. Washington, DC: 2017. doi:10.1596/978-1-46481084-8.

[3] WHO, UNICEF. Progress on Drinking Water, Sanitation and Hygiene: 2017 Update and SDG Baselines. Geneva: 2017.

[4] Bieber N, Ker JH, Wang X, Triantafyllidis C, van Dam KH, Koppelaar RHEM, et al. Sustainable planning of the energy-water-food nexus using decision making tools. Energy Policy 2018;113:584-607. doi:10.1016/J.ENPOL.2017.11.037.

[5] Guta D, Jara J, Adhikari N, Chen Q, Gaur V, Mirzabaev A. Assessment of the Successes and Failures of Decentralized Energy Solutions and Implications for the Water-EnergyFood Security Nexus: Case Studies from Developing Countries. Resources 2017;6:24. doi:10.3390/resources6030024.

[6] Garcia DJ, You F. The water-energy-food nexus and process systems engineering: A new focus. Comput Chem Eng 2016;91:49-67. doi:10.1016/j.compchemeng.2016.03.003.

[7] Hussien WA, Memon FA, Savic DA. An integrated model to evaluate water-energy-food nexus at a household scale. Environ Model Softw 2017;93:366-80. doi:10.1016/J.ENVSOFT.2017.03.034.

[8] Leung Pah Hang MY, Martinez-Hernandez E, Leach M, Yang A. Designing integrated local production systems: A study on the food-energy-water nexus. J Clean Prod 2016;135:106584. doi:10.1016/J.JCLEPRO.2016.06.194.

[9] Brandoni C, Bošnjaković B. HOMER analysis of the water and renewable energy nexus for water-stressed urban areas in Sub-Saharan Africa. J Clean Prod 2017;155:105-18. doi:10.1016/J.JCLEPRO.2016.07.114.

[10] Al-Ansari T, Korre A, Nie Z, Shah N. Development of a life cycle assessment tool for the assessment of food production systems within the energy, water and food nexus. Sustain Prod Consum 2015;2:52-66. doi:10.1016/j.spc.2015.07.005.

[11] Adams TA, Ghouse JH. Polygeneration of fuels and chemicals. Curr Opin Chem Eng 2015;10:87-93. doi:10.1016/j.coche.2015.09.006.

[12] Jana K, Ray A, Majoumerd MM, Assadi M, De S. Polygeneration as a future sustainable energy solution - A comprehensive review. Appl Energy 2017;202:88-111. doi:10.1016/j.apenergy.2017.05.129.

[13] Murugan S, Horák B. Tri and polygeneration systems - A review. Renew Sustain Energy Rev 2016;60:1032-51. doi:10.1016/j.rser.2016.01.127.

[14] Khan EU, Mainali B, Martin A, Silveira S. Techno-economic analysis of small scale biogas based polygeneration systems: Bangladesh case study. Sustain Energy Technol Assessments 2014;7:68-78. doi:10.1016/j.seta.2014.03.004.

[15] Calise F, Macaluso A, Piacentino A, Vanoli L. A novel hybrid polygeneration system 
supplying energy and desalinated water by renewable sources in Pantelleria Island. Energy 2017;137:1086-106. doi:10.1016/j.energy.2017.03.165.

[16] Aichmayer L, Spelling J, Laumert B. Small Scale Hybrid Solar Power Plants for Polygeneration in Rural Areas. Energy Procedia 2014;57:1536-45. doi:10.1016/j.egypro.2014.10.113.

[17] Berrill P, Hertwich EG. Ground truthing the environmental benefits of a polygeneration system: When to combine heat and power? Energy Build 2018;173:221-38. doi:10.1016/J.ENBUILD.2018.05.020.

[18] HOMER Energy LLC. HOMER Pro 2017.

[19] Swarr TE, Hunkeler D, Klöpffer W, Pesonen HL, Ciroth A, Brent AC, et al. Environmental life-cycle costing: A code of practice. Int J Life Cycle Assess 2011;16:389-91. doi:10.1007/s11367-011-0287-5.

[20] ISO. Environmental management - Life cycle assessment - Principles and framework (ISO 14040). Geneva: International Organization for Standardization; 2006.

[21] ISO. Environmental management - Life cycle assessment - Requirements and guidelines (ISO 14044). Geneva: International Organization for Standardization; 2006.

[22] Philippine Department of Energy. 2016-2020 Missionary Electrification Development Plan. Manila: 2016.

[23] Bertheau P, Blechinger P. Resilient solar energy island supply to support SDG7 on the Philippines: Techno-economic optimized electrification strategy for small islands. Util Policy 2018;54:55-77. doi:10.1016/J.JUP.2018.07.005.

[24] Philippine Statistics Authority. 2017 Philippine Statistical Yearbook. Quezon City: 2017.
[25] Philippine Statistics Authority. Population Projection Statistics 2016. https://psa.gov.ph/statistics/census/projected-population (accessed May 30, 2018).

[26] OECD/IEA. World Energy Outlook 2016. Paris: 2016.

[27] WHO, UNICEF. JMP Methodology: 2017 update and SDG baselines. Geneva: 2017.

[28] Meschede H, Holzapfel P, Kadelbach F, Hesselbach J. Classification of global island regarding the opportunity of using RES. Appl Energy 2016;175:251-8. doi:10.1016/j.apenergy.2016.05.018.

[29] Bhatia M, Angelou N. Beyond Connections: Energy Access Redefined. Washington, DC: 2015.

[30] Philippine Statistics Authority. Electricity is the most common source of energy used by households 2013. https://psa.gov.ph/content/electricity-most-common-source-energy-usedhouseholds (accessed June 20, 2017).

[31] World Bank. Philippines Small Towns Water Utilities Data Book. Washington, DC: 2006.

[32] Aberilla JM, Gallego-Schmid A, Stamford L, Azapagic A. Design and environmental sustainability assessment of small-scale off-grid energy systems for remote rural communities. Appl Energy 2020;258:114004. doi:10.1016/j.apenergy.2019.114004.

[33] UN-ESCAP. Asia-Pacific Progress in Sustainable Energy: A Global Tracking Framework 2017 Regional Assessment Report. Bangkok: 2017.

[34] Food and Agriculture Organization. FAOSTAT 2017. http://www.fao.org/faostat/en/\#data/QC (accessed February 13, 2018).

[35] OECD/IEA. Southeast Asia Energy Outlook 2017. Paris: 2017.

[36] United Nations. 2014 Energy Statistics Yearbook. New York: 2016.

[37] Gassert F, Luck M, Landis M, Reig P, Shiao T. Aqueduct Global Maps 2.1: Constructing Decision-Relevant Global Water Risk Indicators. Washington, DC: 2014.

[38] World Bank. Technical and economic assessment of off-grid, mini-grid and grid electrification technologies. Washington, DC: 2007.

[39] IRENA. Electricity Storage and Renewables for Island Power: A Guide for Decision Makers. Abu Dhabi: 2012.

[40] Philippine Statistics Authority. Philippine Statistical Yearbook. Quezon City, Philippines: 2016.

[41] Elauria JC, Castro MLY, Elauria MM, Bhattacharya SC, Salam PA. Assessment of sustainable energy potential of non-plantation biomass resources in the Philippines. Biomass and Bioenergy 2005;29:191-8. doi:10.1016/j.biombioe.2005.03.007.

[42] IRENA. Renewable Power Generation Costs in 2017. Abu Dhabi: 2018.

[43] OECD/IEA. World Energy Outlook 2017. Paris: 2017. 
[44] IRENA. The Power to Change: Solar and Wind Cost Reduction Potential to 2025. Abu Dhabi: 2016.

[45] IRENA. Electricity storage and renewables: Costs and markets to 2030. Abu Dhabi: 2017.

[46] World Bank Group. Commodity Markets Outlook. Washington, DC: 2017.

[47] Lazard. Lazard's Levelized Cost of Energy Analysis - version 11.0. 2017.

[48] IndexMundi. Propane - Daily Price - Commodity Prices 2018. https://www.indexmundi.com/commodities/?commodity=propane (accessed July 6, 2018).

[49] Orrell AC, Foster NF, Morris SL, Homer JS. 2016 Distributed Wind Market Report. Richland, Washington: 2017.

[50] IRENA. Renewable Energy Cost Analysis: Wind Power. Abu Dhabi: 2012.

[51] IRENA. Renewable Energy Cost Analysis: Biomass for Power Generation. vol. 1. Abu Dhabi: 2012.

[52] Lazard. Lazard's Levelized Cost of Storage Analysis - version 3.0. 2017.

[53] Afrane G, Ntiamoah A. Analysis of the life-cycle costs and environmental impacts of cooking fuels used in Ghana. Appl Energy 2012;98:301-6. doi:10.1016/j.apenergy.2012.03.041.

[54] Wilson DL, Talancon DR, Winslow RL, Linares X, Gadgil AJ. Avoided emissions of a fuelefficient biomass cookstove dwarf embodied emissions. Dev Eng 2016;1:45-52. doi:10.1016/j.deveng.2016.01.001.

[55] Jana C, Bhattacharya SC. Sustainable cooking energy options for rural poor people in India: an empirical study. Environ Dev Sustain 2017;19:921-37. doi:10.1007/s10668-016-9774-y.

[56] Baron GP. Home biogas system (Philippine BioDigesters) - Appropedia: The sustainability wiki. Appropedia

http://www.appropedia.org/Home_biogas_system_(Philippine_BioDigesters) (accessed November 6, 2018).

[57] Marchionni V, Cabral M, Amado C, Covas D. Estimating Water Supply Infrastructure Cost Using Regression Techniques. J Water Resour Plan Manag 2016;142:04016003. doi:10.1061/(ASCE)WR.1943-5452.0000627.

[58] Towler G, Sinnott R. Chemical Engineering Design. 2nd ed. Oxford: ButterworthHeinemann; 2013. doi:10.1016/B978-0-08-096659-5.00007-9.

[59] Banat F, Jwaied N. Economic evaluation of desalination by small-scale autonomous solarpowered membrane distillation units. Desalination 2008;220:566-73. doi:10.1016/J.DESAL.2007.01.057.

[60] Kosmadakis G, Manolakos D, Kyritsis S, Papadakis G. Economic assessment of a twostage solar organic Rankine cycle for reverse osmosis desalination. Renew Energy 2009;34:1579-86. doi:10.1016/J.RENENE.2008.11.007.

[61] Garg MC, Joshi H. Optimization and economic analysis for a small scale nanofiltration and reverse osmosis water desalination system. Water Sci Technol Water Supply 2015;15:1027-33. doi:10.2166/ws.2015.059.

[62] Papapetrou M, Cipollina A, La Commare U, Micale G, Zaragoza G, Kosmadakis G. Assessment of methodologies and data used to calculate desalination costs. Desalination 2017;419:8-19. doi:10.1016/J.DESAL.2017.05.038.

[63] Shahabi MP, Mchugh A, Ho G. Environmental and economic assessment of beach well intake versus open intake for seawater reverse osmosis desalination. Desalination 2014;357:259-66. doi:10.1016/j.desal.2014.12.003.

[64] Ettouney HM, El-Dessouky HT, Faibish RS, Gowin PJ. Evaluating the economics of desalination. Chem Eng Prog 2002;98:32-9. doi:10.1016/j.desal.2010.02.032.

[65] Department of Trade and Industry Philippines. e-Presyo 2018. https://www.dti.gov.ph/consumers/e-presyo (accessed December 5, 2018).

[66] Philippine Primer. Drinking Water in the Philippines 2015. http://primer.com.ph/business/2015/01/27/drinking-water-in-the-philippines/ (accessed November 23, 2018).

[67] Conergy Asia. References - Solar Farms n.d. http://asia.conergy.com/solarinstallations/references/ (accessed November 6, 2018).

[68] Jungbluth N, Stucki M, Flury K, Frischknecht R, Büsser S. Life Cycle Inventories of Photovoltaics. 2012.

[69] Wernet G, Bauer C, Steubing B, Reinhard J, Moreno-Ruiz E, Weidema B. The ecoinvent database version 3 (part I): overview and methodology. Int $\mathrm{J}$ Life Cycle Assess 
2016;21:1218-30. doi:10.1007/s11367-016-1087-8.

[70] Kabir MR, Rooke B, Dassanayake GDM, Fleck BA. Comparative life cycle energy, emission, and economic analysis of $100 \mathrm{~kW}$ nameplate wind power generation. Renew Energy 2012;37:133-41. doi:10.1016/j.renene.2011.06.003.

[71] Benton K, Yang X, Wang Z. Life cycle energy assessment of a standby diesel generator set. J Clean Prod 2017;149:265-74. doi:10.1016/j.jclepro.2017.02.082.

[72] Notter DA, Gauch M, Widmer R, Wäger P, Stamp A, Zah R, et al. Contribution of Li-lon Batteries to the Environmental Impact of Electric Vehicles. Environ Sci Technol 2010;44:6550-6. doi:10.1021/es903729a.

[73] Adams PWR. An Assessment of UK Bioenergy Production, Resource Availability, Biomass Gasification, and Life Cycle Environmental Impacts. University of Bath, 2011.

[74] Aberilla JM, Gallego-Schmid A, Azapagic A. Environmental sustainability of small-scale biomass power technologies for agricultural communities in developing countries. Renew Energy 2019;141:493-506. doi:10.1016/j.renene.2019.04.036.

[75] Jungbluth N. Life-Cycle-Assessment for Stoves and Ovens. Zurich: 1997.

[76] Singh P, Gundimeda H, Stucki M. Environmental footprint of cooking fuels: a life cycle assessment of ten fuel sources used in Indian households. Int $\mathrm{J}$ Life Cycle Assess 2014;19:1036-48. doi:10.1007/s11367-014-0699-0.

[77] Morelli B, Cashman S, Rodgers M. Life Cycle Assessment of Cooking Fuel Systems in India, China, Kenya and Ghana. Lexington, MA: 2017.

[78] Aberilla JM, Gallego-Schmid A, Stamford L, Azapagic A. Environmental sustainability of cooking fuels in remote communities: Life cycle and local impacts. Sci Total Environ 2020;713:136445. doi:10.1016/j.scitotenv.2019.136445.

[79] Pradeleix L, Roux P, Bouarfa S, Jaouani B, Lili-Chabaane Z, Bellon-Maurel V. Environmental Impacts of Contrasted Groundwater Pumping Systems Assessed by Life Cycle Assessment Methodology: Contribution to the Water-Energy Nexus Study. Irrig Drain 2015;64:124-38. doi:10.1002/ird.1865.

[80] Cherif $\mathrm{H}$, Champenois G, Belhadj J. Environmental life cycle analysis of a water pumping and desalination process powered by intermittent renewable energy sources. Renew Sustain Energy Rev 2016;59:1504-13. doi:10.1016/j.rser.2016.01.094.

[81] Aberilla JM. Sustainability Assessment of Energy and Water Syner-generation for Remote Communities. PhD thesis. The University of Manchester, 2020.

[82] Garfí M, Cadena E, Sanchez-Ramos D, Ferrer I. Life cycle assessment of drinking water: Comparing conventional water treatment, reverse osmosis and mineral water in glass and plastic bottles. J Clean Prod 2016;137:997-1003. doi:10.1016/J.JCLEPRO.2016.07.218.

[83] Thinkstep. GaBi Software-System and Database for Life Cycle Engineering 2016.

[84] Goedkoop M, Heijungs R, Huijbregts M, De Schryver A, Struijs J, Van Zelm R. ReCiPe 2008 version 1.08. The Hague: 2013.

[85] Vásquez WF. Understanding bottled water consumption in a high-poverty context: empirical evidence from a small town in Guatemala. Int J Consum Stud 2017;41:199-206. doi:10.1111/ijcs.12327.

[86] Francisco JPS. Why households buy bottled water: a survey of household perceptions in the Philippines. Int J Consum Stud 2014;38:98-103. doi:10.1111/ijcs.12069.

[87] WWI. The Aftermath Restoring Water in The Philippines. Water Wastewater Int 2013:23.

[88] CFE-DM. ASEAN Disaster Management Reference Handbook. JBPHH, Hawaii: 2019. 
Synergistic generation of energy and water in remote communities:

Economic and environmental assessment of current situation and future scenarios

Jhud Mikhail Aberilla, Alejandro Gallego-Schmid, Laurence Stamford and Adisa Azapagic

\section{Supplementary Information}

\section{Nomenclature}

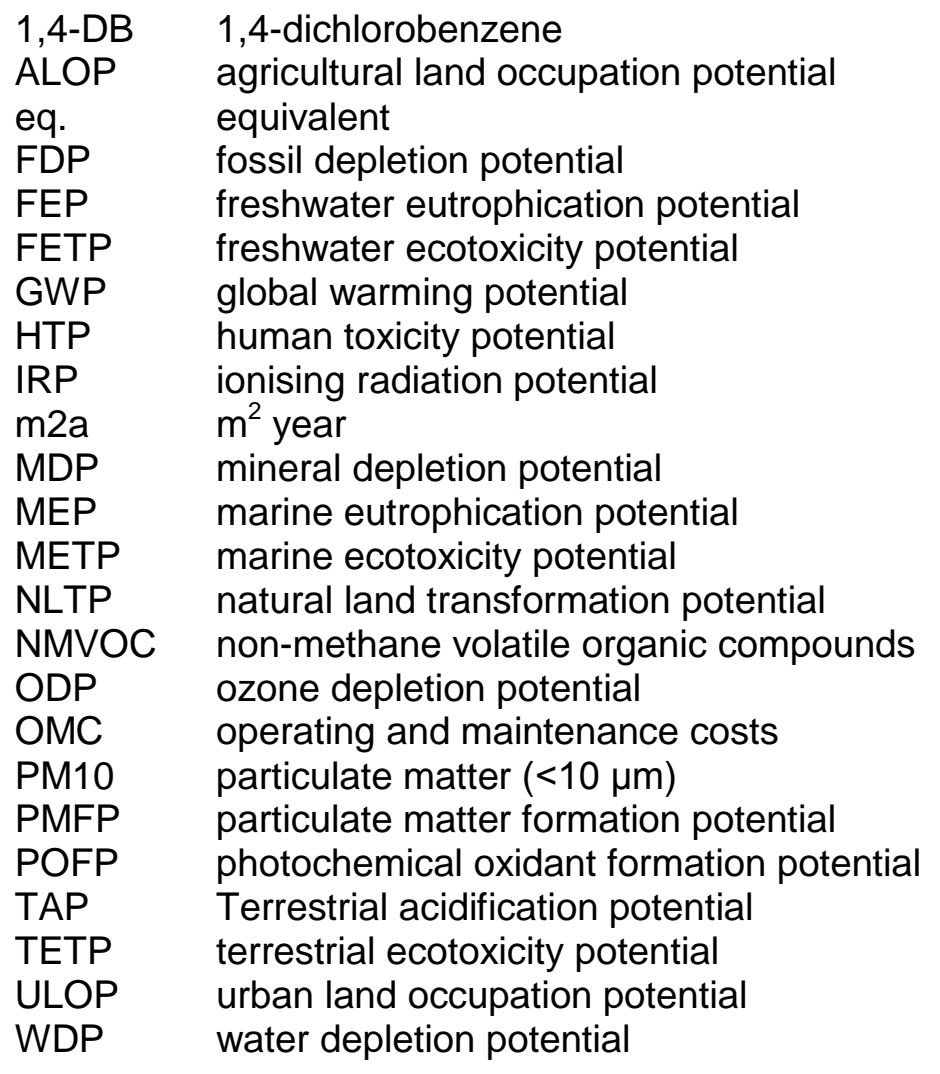

Table S1. Life cycle environmental impacts of electricity for the current situation and future scenarios

\begin{tabular}{|c|c|c|c|c|}
\hline Annual impact per household ${ }^{\mathrm{a}}$ & Current situation & Business as usual & Transition & Independent \\
\hline GWP (kg CO ${ }_{2}$ eq. $)$ & 100.9 & 115.5 & 15.4 & -0.4 \\
\hline ODP (mg CFC- 11 eq.) & 18.8 & 21.6 & -0.6 & -0.1 \\
\hline PMFP x10 (g PM 10 eq.) & 58.2 & 66.7 & -3.3 & 0.4 \\
\hline POFP x100 (g NMVOC) & 17.5 & 20.0 & 0.3 & 0.3 \\
\hline FEP x10 (g P eq.) & 0.3 & 0.4 & -39.9 & 0.02 \\
\hline MEP $\times 10$ (g N eq.) & 6.3 & 7.2 & -35.6 & 0.1 \\
\hline TAP x10 (g SO ${ }_{2}$ eq.) & 108.7 & 124.3 & -23.9 & 1.5 \\
\hline FETP x10 (g 1,4-DB eq.) & 92.8 & 98.7 & -29.5 & 3.0 \\
\hline METP $\times 10$ (g 1,4-DB eq.) & 77.9 & 82.9 & -24.6 & 2.6 \\
\hline TETP (g 1,4-DB eq.) & 9.1 & 10.5 & 49.5 & 44.3 \\
\hline FDP (kg oil eq.) & 34.0 & 39.0 & -1.6 & -0.4 \\
\hline MDP $x 100$ (g Fe eq.) & 10.4 & 10.7 & 0.4 & 5.7 \\
\hline $\operatorname{WDP}\left(\mathrm{m}^{3}\right)$ & 24.9 & 26.7 & -5.2 & 4.2 \\
\hline $\operatorname{ALOP}\left(\mathrm{dm}^{2} \mathrm{a}\right)$ & 98.1 & 110.3 & -14.0 & -3.5 \\
\hline $\operatorname{NLTP} \times 10\left(\mathrm{~cm}^{2}\right)$ & 23.9 & 27.5 & -0.5 & 0.3 \\
\hline ULOP x0.1 (m²a) & 1.8 & 2.0 & -4.9 & 1.3 \\
\hline HTP x10 (g 1,4-DB eq.) & 743.1 & 821.2 & 701.1 & 936.7 \\
\hline IRP $\times 100$ (g U U $^{235}$ eq. $)$ & 83.0 & 95.3 & -4.2 & -0.6 \\
\hline
\end{tabular}


Table S2. Life cycle environmental impacts of cooking heat the current situation and future scenarios

\begin{tabular}{|c|c|c|c|c|}
\hline Annual impact per household ${ }^{a}$ & Current situation & Business as usual & Transition & Independent \\
\hline GWP x10 (kg CO ${ }_{2}$ eq.) & 69.2 & 64.4 & 60.2 & 50.5 \\
\hline ODP (mg CFC- 11 eq.) & 72.7 & 73.1 & 43.1 & -4.0 \\
\hline PMFP x100 (g PM 10 eq.) & 102.6 & 39.7 & 76.5 & 97.3 \\
\hline POFP (kg NMVOC) & 38.6 & 17.2 & 25.9 & 34.6 \\
\hline FEP x100 (g P eq.) & 4.2 & -18.6 & -27.2 & -34.0 \\
\hline MEP $\times 100$ (g N eq.) & 0.7 & -17.8 & -26.6 & -33.8 \\
\hline TAP x100 ( $\mathrm{g} \mathrm{SO}_{2}$ eq. $)$ & 19.6 & 3.2 & -9.3 & -13.9 \\
\hline FETP $\times 100$ (g 1,4-DB eq.) & 52.0 & 34.7 & 22.3 & 0.6 \\
\hline METP x100 (g 1,4-DB eq.) & 43.9 & 28.9 & 19.2 & 1.5 \\
\hline TETP x10 (g 1,4-DB eq.) & 26.5 & 16.3 & 24.2 & 30.7 \\
\hline FDP (kg oil eq.) & 135.9 & 135.8 & 79.3 & -9.0 \\
\hline MDP (kg Fe eq.) & 18.7 & 21.5 & 18.5 & 13.5 \\
\hline $\mathrm{WDP}\left(\mathrm{m}^{3}\right)$ & 154.9 & 158.2 & 111.3 & 40.2 \\
\hline ALOP $\times 0.1\left(\mathrm{~m}^{2} \mathrm{a}\right)$ & 42.2 & 39.9 & 27.4 & -1.3 \\
\hline NLTP $\times 10\left(\mathrm{~cm}^{2}\right)$ & 105.2 & 106.8 & 61.7 & -8.5 \\
\hline $\operatorname{ULOP}\left(\mathrm{m}^{2} \mathrm{a}\right)$ & 0.8 & -1.5 & -2.8 & -4.1 \\
\hline HTP x10 (kg 1,4-DB eq.) & 30.8 & 14.1 & 20.5 & 23.9 \\
\hline IRP ( $\mathrm{kg} \mathrm{U} \mathrm{23}^{5} \mathrm{eq}$.) & 30.5 & 29.8 & 17.3 & -2.3 \\
\hline
\end{tabular}

${ }^{\mathrm{a}}$ For the acronyms, see the Nomenclature section.

Table S3. Life cycle environmental impacts of water for the current situation and future scenarios

\begin{tabular}{|c|c|c|c|c|}
\hline Annual impact per household ${ }^{a}$ & Current situation & Business as usual & Transition & Independent \\
\hline GWP $\times 100\left(\mathrm{~kg} \mathrm{CO}_{2}\right.$ eq. $)$ & 9.2 & 15.5 & 6.6 & 0.1 \\
\hline ODP $\times 10$ (mg CFC- 11 eq.) & 11.4 & 19.6 & 8.2 & 0.1 \\
\hline PMFP x100 (g PM 10 eq.) & 19.2 & 31.3 & 11.8 & 0.4 \\
\hline POFP x100 (g NMVOC) & 39.8 & 62.7 & 23.8 & 1.1 \\
\hline FEP x10 (g P eq.) & 26.7 & 46.2 & -39.4 & 0.4 \\
\hline MEP x100 (g N eq.) & 10.5 & 17.7 & 2.0 & 0.1 \\
\hline TAP x100 (g SO 2 eq.) & 53.0 & 88.2 & 32.3 & 1.2 \\
\hline FETP (kg 1,4-DB eq.) & 58.5 & 100.8 & 42.5 & 0.8 \\
\hline METP (kg 1,4-DB eq.) & 48.5 & 83.6 & 35.2 & 0.7 \\
\hline TETP $\times 10$ (g 1,4-DB eq.) & 16.0 & 27.0 & 18.5 & 10.4 \\
\hline FDP $\times 10$ (kg oil eq.) & 35.3 & 59.2 & 23.9 & 0.2 \\
\hline MDP (kg Fe eq.) & 45.7 & 76.9 & 33.4 & 3.7 \\
\hline WDP $\times 100\left(\mathrm{~m}^{3}\right)$ & 20.5 & 33.9 & 15.4 & 1.9 \\
\hline $\operatorname{ALOP}\left(m^{2} a\right)$ & 49.4 & 83.2 & 34.1 & 0.5 \\
\hline $\operatorname{NLTP}\left(\mathrm{dm}^{2}\right)$ & 9.0 & 14.9 & 5.8 & 0.1 \\
\hline $\operatorname{ULOP}\left(\mathrm{m}^{2} \mathrm{a}\right)$ & 8.4 & 14.3 & 5.4 & 0.5 \\
\hline HTP x10 (kg 1,4-DB eq.) & 51.8 & 89.3 & 39.1 & 2.9 \\
\hline IRP $\times 10$ (kg U235 eq. $)$ & 7.8 & 13.3 & 5.5 & 0.1 \\
\hline
\end{tabular}



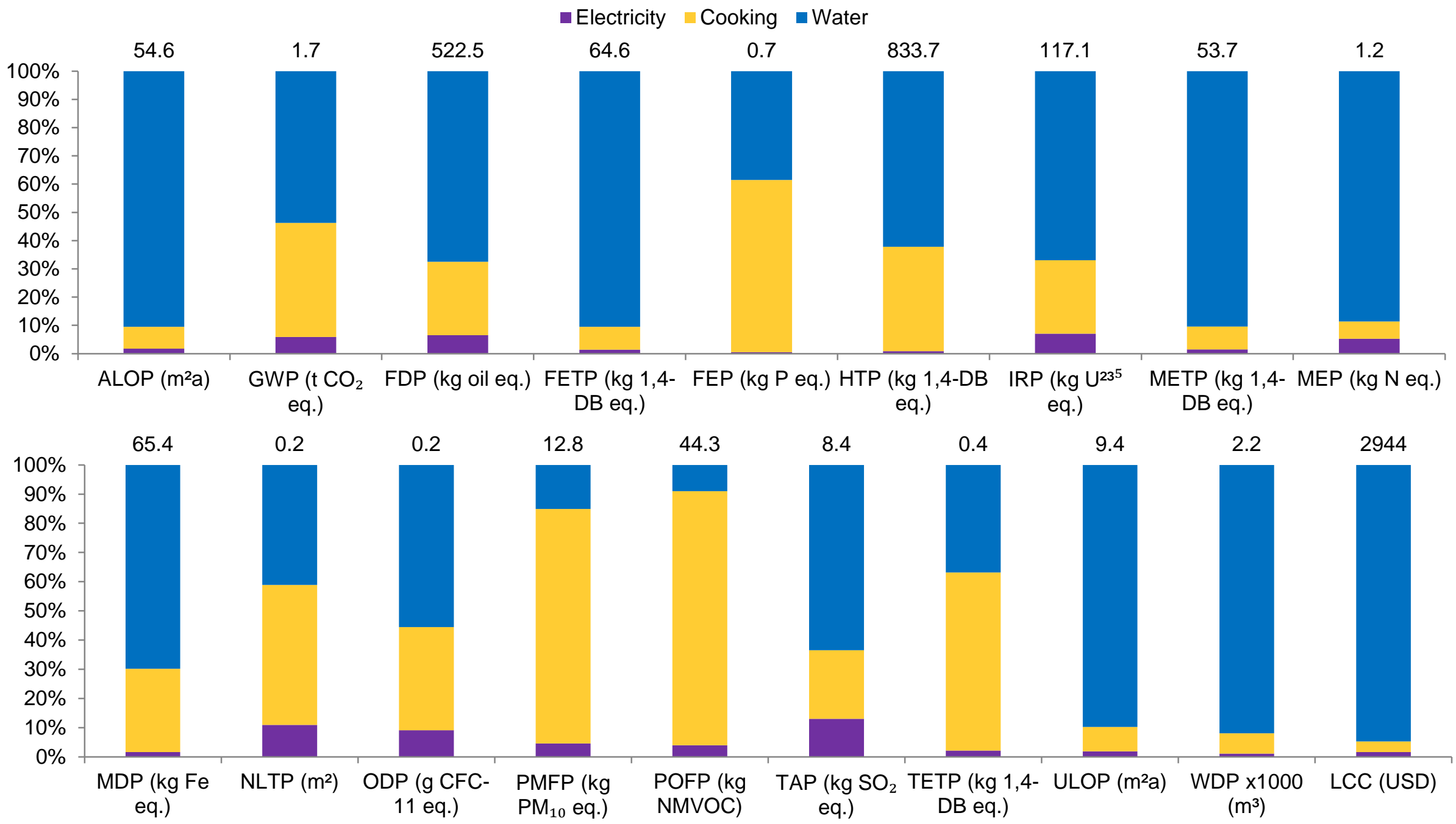

Figure S1. Annual environmental impacts and levelised cost per household for the current situation [Data labels represent total cradle-to-grave impacts. For the acronyms, see the Nomenclature section] 